\title{
CONTEMPORARY AFRICAN POLITICAL PARTIES \\ Institutionalisation for the Sustainability of Democracy
}

\author{
Sulaiman Balarabe Kura
}

International Development Department

Priorsfield, University of Birmingham

46 Edgbaston Park Road Birmingham, B15 2RT, United Kingdom

Tel: +44 (0) 1214142674

Fax: +44 (0) 1214145032

email: sulaimankura@yahoo.co.in

syk408@bham.ac.uk

\begin{abstract}
Political parties are the custodians of democracy. Following the return of democracy to Africa during the 'third' and 'fourth' waves, political parties are undergoing structural changes (from military and one-party authoritarianism to liberal multiparty systems) for the development of sustainable democracy. This paper is not about institutionalised political parties or party systems, it is about understanding the historical development of political parties and their transformational nature in relation to the development of democracy in Africa. The paper therefore identifies some critical challenges that are threatening the institutionalisation process of the parties. These include party funding and finance, party ideology, the dominant-party syndrome, ineffective civil society opposition and problems of fragile electoral institutions. The paper argues that though these problems are part of the wider socio-political and economic dilemmas inherent in Africa they are more pervasive and have a devastating affect on political parties as instruments of modern representative democracy. The paper thus contends that, given the main concerns and attributes of good governance, it is the only panacea that can wholly address the institutional problems of political parties as well as other structural and institutional obstacles to the development of sustainable democracy in Africa. Good governance is presumed here to be the ideal and pragmatic solution to such institutional obstacles.
\end{abstract}




\section{INTRODUCTION}

The collapse of command political and economic socialist and communist regimes in Eastern and Southern Europe (former members of the Soviet Union) in the last decades of the 20th century caused great turmoil in the political and social histories of many countries. Globally, it led to the end of the East-West rivalry popularly known as the Cold War. Most importantly, it led to the proliferation of democracy and democratic governance in several countries hitherto under military dictatorships and one-party regimes. In Africa many countries haphazardly embraced the new project of re-democratisation and, where democracy was already the norm, reforms were introduced.

Political parties, as the custodian of modern representative liberal democracy, were at the forefront of these shifts from authoritarianism to liberal democracy. All over the continent there were complete overhauls of dictatorial regimes or one-party systems forcibly gave way to multipartyism. In countries where dictatorships continued to hold sway, such as Zaire, Sierra Leone, Liberia, and even Zimbabwe, civil wars and instability became the order of the day.

The centrality of political parties to democracy has been well documented in the literature of political science. Democratic systems cannot do without them and even non-democratic regimes used them in disguise. For example, Cuba, North Korea, China, Saddam's Iraq, Hitler's Germany, other totalitarian regimes, and some monarchical states in the Middle East had or have political parties. The proliferation of democracy at the turn of the last century has also been coloured by the upsurge of political parties in Africa. From South Africa to Egypt; Nigeria to Ethiopia, it is accepted that political parties are at the centre stage of democratic reforms. However, despite their centrality, political parties are today being attacked from all sides. Other social and political institutions are robbing them of their most serious and important functions.

Against this gloomy background, are political parties in Africa late in making a meaningful impact in their role as custodians of democracy or are they in the process of institutionalisation in order to embrace the norms and ideals of democratisation and contain the challenges posed by domestic and external factors? This paper attempts to explore the contemporary state of political parties with a view to highlighting the crisis facing them in Africa today and identifying the potential for institutionalisation in the development of sustainable democracy. Institutionalisation is the process by which democratic values and norms become deeply embedded in the organisation of political parties. It is the process of creating credible and stable political parties.

The paper is divided into five parts and subsections: part one is this introduction; part two contains theoretical and conceptual framework issues 
relating to political parties, their traditional role and the changing nature of this role in the development of democracy; part three concentrates on the historical development of African political parties and their classification within the universal discourse of party politics; part four is devoted to identifying some fundamental issues that could obstruct the rapid institutionalisation of political parties vis-à-vis the development of sustainable democracy in Africa, and also recommends a good governance framework for overcoming these challenges and nurturing institutionalised parties. The last part sums up and concludes the paper.

\section{CONCEPTUAL FRAMEWORK: POLITICAL PARTIES AND INSTITUTIONALISATION}

Political parties are organisations whose members have values, ideals and aspirations in common and which participate in the organised contest/struggles for political power. Coleman and Roseberg (cited in Smith 1996, p 96) defined political parties as associations formally organised with the explicit and declared purpose of acquiring, and to some extent maintaining, either singly or in coalition or electoral competition with other associations, legal control over the personnel and the policy of the government of an actual or prospective sovereign state.

This definition is similar to that of Henig and Pinder (1969, p 11), who defined political parties as groups of people acting together to achieve some political goals, including appropriate control of government. Parties are simply organised or loosely organised group under a recognised label with the sole intention of controlling power through elections (Epstein 1967). Janda (1980, p 5) stresses that a party is an organisation that simply pursues a goal of placing its avowed representatives in government positions.

Sartori (1976, p 63) provides one of the most widely quoted definitions of political parties. He stresses that a political party is 'any political group identified by an official label that presents at elections, and is capable of placing through elections (free or non-free), candidates for public office'. While this definition is a step forward from those above because it includes 'free and non-free' elections, it cannot be used to define contemporary parties in developing countries because of the vulnerability of the parties to manipulation and the extensive role played by the state in their activities.

Accordingly, some scholars define parties in accordance with their functions in governance and administration. Thus, there is party government or partocracy. From this perspective, Katz (1986, pp 31-71) suggests some ways of identifying party government vis-à-vis defining a political party. According to Katz party government involves: 
- the making of governmental decisions by elected party officials or by those directly or indirectly under their control;

- government policy decided within political parties;

- parties acting cohesively to enact and implement this policy;

- public officials being recruited through political parties;

- public officials being held accountable through political parties.

Defining political parties on these lines is not only ambiguous but also narrows down their functions solely to the formation of government. Parties have also been conceptualised in terms of the scope of their activities. Catto (2000, pp 5974) conceives parties in terms of their place in the legislature, as organisations in the electorate, in government, in bureaucracy, and as systems. This has further complicated the idea of having a working definition(s) for the study of political parties, especially in emerging democracies in Africa. For example, party is also defined as a membership organisation. Thus, it constitutes a 'focal and rallying point for citizens actively interested in politics' and 'also a community taking care of many needs ranging from social protection to education, to leisure activities and even to personal relationships' (Catto 2000, p 63). Parties have also been defined as a set of individuals with common political interests, values, aspirations, ideals, strategies and programmes (Ware 1996; Sartori 1976). Parties are more than sets of individuals. No matter how organised sets of individuals are, they can not be labelled political parties except when their overall objective is to acquire political power and when they are recognised at least by the relevant institutions of the state.

Certain trajectories run through most of the definitions of political parties:

- Political parties are formal political organisations.

- Their major goal is to win control of state power.

- They run candidates in elections.

- Contesting elections is the underlying framework through which they form government.

- They operate in both democratic and non-democratic regimes.

- They have an 'avowedly public purpose as broad coalitions that facilitate compromise and governance in society as a whole' (Thomas, 2001, p 5).

- They have a label that is institutionally recognised.

The greatest problem in defining parties centres on the narrow and broad views and the extent to which such definitions influence whether the general theory is limited only to explaining and discussing the manner and political behaviour of 
purely competitive parties (as is the case in stable advanced democracies) or whether it aims at a broader concept, embracing even single-party systems and anti-systems or subversive parties in autocratic-democratic regimes (Janda 1993, p166). This is an important theoretical debate but the scope and limitation of this paper does not allow the issue to be probed. Nevertheless, trying to minimise the problems of conceptualisation Lawson (1976, pp 3-4) argues that 'a political party is an organisation of individuals that seeks continuing electoral and nonelectoral authorisation from the public (or a portion thereof) for specified representatives of that organisation to exercise the political power of particular government offices, claiming that such power would be exercised on behalf of that public.'

The definitions above did not recognise the officialness of parties as organisations before apparently qualifying as political parties, especially in some African countries. On this note political parties are formally recognised organisations whose members share certain common values, ideals and aspirations about how society should be politically, socio-culturally and economically organised for the common good and aspire to put into practice these ideals and values through the control of government. This is done by placing their representatives in competitive, free and fairly conducted elections without or with minimal harassment, intimidation and threats of violence.

The concept of parties in this context captures the broad understanding of their role and could be applied to the study of developing democracies. In this respect the definition also identifies the nature of parties in both new and old democracies. Although this definition of a political party seems too ambitious it captures clearly the basic requirements of a party that is capable of impacting on democratic governance. The definition includes African political parties but, importantly, it exposes the questionable nature and characteristics of these parties. This is why most African political parties are part of the problem of democratisation on the continent. At any rate the definition is only a working guide for understanding how African political parties negate the avowed principles of democratic competition and politicking.

In the new democracies parties are still in their infancy and many were formed along ethnic, tribal, even, in some cases, religious lines. In short, parties reflect the apparent socio-cultural and political cleavages and divisions in a society. Thus, parties in developing democracies cannot be compared to those in advanced democracies, though some might argue that it is imperative to compare African political parties with Western parties, particularly because the dominant approach to party research is heavily influenced by Western authors drawing on their historical experiences.

Parties as political associations are officially recognised as participants in the political process in their respective countries, hence they are, to a very 
significant degree, identified as political parties. Non-party-recognised organisations, no matter the extent of their objective and administrative articulation, are not termed political parties until they are officially and formally recognised as such. That is, perhaps, why parties are required to be constitutionally registered before they can fully participate in the contest for power.

The above arguments make it both theoretically and empirically clear that democratisation and political parties are two sides of the same coin. Democracy can only be practised in terms of political parties. Despite the widespread arguments against the continued relevance or decline of political parties (Schmitter 2001) parties are the most important organisations in modern politics and only a few non-democratic states do without them, though even non-democratic states use them in disguise to advance their authoritarian rule. For example, the Nazi Party in Hitler's Germany, the Communist Party of China, the Partido Commusita de Cuba (PCC) or the Workers' Party of Korea, the Korean Social Democratic Party, the Chondoist Chongu Party and Democratic Front for the Liberation of Korea in North Korea.

In other words, even non-democratic regimes cannot do without political parties, because they remain the rallying point for 'support' and / or 'opposition'. The reason why they are 'well-nigh ubiquitous is that they perform functions that are valuable to many political actors' (Strøm \& Miller 1999, p 1). Moreover, accepting the centrality of parties, David $(1976, \mathrm{p} 1)$ argues that to talk of democracy is to talk about competitive parties that underscore the representative model of liberal democracy since the French Revolution. More fundamentally, a political party is the most essential factor in the consolidation of democracy, even though other factors such as civil society, rule of law, free and fair elections or transparency and accountability are also important (Van Biezen 2003, p 4). This is simply because of the enormous role played by political parties (see Diamond 1997, p xxiii).

Invariably, from whichever angle one looks at the issue of democratisation, political parties still matter. They remain the primary representative and legitimising links between citizens and the state. They are the principal legitimate means through which citizens can hold their leaders accountable for policy and performance. Furthermore, Katz (1992, p 1) stresses that to date no political institution is assigned the particular principal responsibility of formation and maintenance of government. Even in countries which have had long military dictatorship or other forms of autocratic leadership the formation of political parties is the first identifiable step towards democratisation, in whichever form it starts, be it elite consensus or otherwise.

Since the massive 'waves' of democratisation across Africa, political parties have been conditioned formally and/or informally to undertake reforms and 
other essential changes in order to adapt to the demands of multiparty democracy. This is against hitherto underlying norms of one-party and military dictatorships. It is in this context, and in the context of the history of the African democratic struggle, that parties are perceived to be in crises of transformation for institutionalisation vis-à-vis democratic consolidation.

\section{POLITICAL PARTIES AND THE DEVELOPMENT OF DEMOCRACY}

Today, the centrality of political parties in democracy is acknowledged everywhere in the world, even where 'ideal' parties are conspicuously absent or their functions are thwarted by extra-legal and extra-democratic measures. In fact, because of their centrality, political party literature continues to be the best source of research for political scientists (see Reiter 2007). Apart from the period during the two world wars, there have been consistent studies of and research into political parties since the 1800s. Strøm \& Miller (1999, p 1) observe that:

Political parties are the most important organisations in modern politics. In the contemporary world, only a few states do without them. The reason that political parties are well nigh ubiquitous is that they perform functions that are valuable to many political actors ... Democracy may be conceived as a process by which voters delegate policy-making authority to a set of representatives and political parties are the main organisational vehicle by which such delegation takes place.

The position occupied by political parties in modern representative democracy has not only made political scientists conceptualise democracy itself along party political lines but also stress that 'to talk, today, about democracy, is to talk about a system of competitive political parties' (Robertson 1976, p 1). It is perhaps because of the essential role of parties in all aspects of the political and economic life of political beings and because to date no institution has replaced those functions that, despite the debate about the decaying and 'withering' away of the 'golden' age of political parties, parties continue to be the cornerstone of redemocratisation in developed democracies and, especially, in the emerging democracies of Eastern Europe, Latin America and Sub-Saharan Africa.

At this point, at least, for convenience of analysis, policy-makers and democratic stakeholders should concentrate on the 'consolidation' and 'institutionalisation' of political parties in developing countries with a view to finding viable ways of making them responsive and responsible to practical democratic governance networks. 
There are pragmatic reasons for making a genuine case for political parties and the thinking that they are indispensable to the establishment and development of democracy and democratic governance.

- They serve as bridge between the government and the governed.

- They serve as the machinery for political mobilisation and political education. They reinforce the activities of formal educational institutions and national and local orientation and mobilisation agencies, thus serving as instruments of civic education. They perform this function by the use of mass media, political rallies, campaigns and local organisations.

- They are agents of political integration and national unity. All societies face problems of integration and unity but the problem is more pervasive and severe in Third World societies. Thus, national parties serve as instruments through which people of different ethnic groups, social norms and political values and orientations come together to advance the course of national and local political societies. ${ }^{1}$

- They are a means of political (leadership) recruitment. They prepare, groom and, consequently, recruit political officers by means of the nomination, selection and election of party candidates to various levels of political office.

- They serve as instruments of accountability. Through political parties the electorate holds its leaders accountable for policies and other governance issues.

- They are mechanisms of representation, representing various groups and sections of the population. They are instruments through which citizens express their opinions and feel represented in governance. In this way, they serve as avenues of political participation. This is the central attribute of representative and participatory democracy.

- They are agencies of governance. The winning party(ies) form and establish the government. They formulate and implement public policies that are supposedly derived from popular demands. They govern and regulate the economic, political and social affairs of the state. As parties engage in the domestic governance of the state they are also involved in formulation of foreign policy. Because of this they are instruments of both national and foreign policy administration and governance. That is why, in order to provide the public

1 The return of democracy through the activities of political parties in Liberia, Rwanda, Congo (Kinshasa and Brazzaville) and several other countries in Africa and elsewhere after many years of civil unrest is testimony to the integrative role of parties. However, their integrative function has been cited as one of the important reasons for the development of one-party regimes in Africa (see Huntington 1968). 
with real options, political parties must be differentiated and distinguished by their philosophies and ideologies.

These are the conventional functions of political parties as indispensable pillars of modern representative democracy. However, not all parties actually perform these functions. Hence, today, there are democracies and quasi-democracies, the latter defined in terms of the problematic nature of the activities of political parties. The intensity with which parties in different political systems perform these functions is explained by economic, political and social factors defined by both historical and contemporary circumstances. In the case of Africa, Tordoff (1988) and Salih (2003) have examined how at various times African political parties have performed these functions in terms of the historical and socio-economic circumstances of the continent.

Despite the important role political parties play in institutionalising modern representative democracies, there is today an emerging debate about the apparent decline of these roles; what some call a crisis of parties (Ignazi 1996, pp 549-66). However, in the following section, it is argued that though parties face serious challenges from old and new political stakeholders their roles are only changing to contend with the enormous challenges and contemporary realities of deepening democracy and democratisation.

\section{CHANGING FUNCTIONS OF PARTIES IN CONTEMPORARY DEMOCRACY}

Although African third-and fourth-wave democracies ${ }^{2}$ are gearing up to develop political parties for electoral competition and democratic consolidation it seems this aspiration coincides with the prediction of some political analysts of the 'downfall' of political parties. Are parties really in crisis? Do other associations

2 According to Huntington (1996, p 199) democracy developed historically in a succession of long waves. The first began in the 19th century with the extension of suffrage to a large number of people, including women, in the US and Western Europe and lasted until the 1920s. In the course of this period, about 29 democratic countries emerged. The rise of totalitarianism in Mussolini's Italy and Hitler's Germany in 1922 reversed this development and the number of democracies dropped to just 12 states. The second wave started in 1962, when the number of democracies increased to 36 states. This period, according to Huntington, lasted until the mid-1970s, when the number was reduced to 30. However, from 1974, especially with democracy taking over in Portugal, the number doubled. Following the collapse of communism in Eastern Europe and the disintegration of many military and one-party systems, democracy scholars perceived this transformation as the 'third wave' and those following it as a 'fourth wave', during which many African countries become 'democracies'. However, it is important to note that Huntington did not forecast the possibility of an ebbing of third-wave or even fourth-wave democracies in the 21st century. What is clear, though, is that economic development and political leadership are decisive factors for democracy. 
exist that could replace their functions? Is the role of political parties being transformed by political and economic globalisation? What, then, will be the fate of African parties, and what challenges are they facing in institutionalising and / or consolidating democracy?

This paper will not explore these questions but will, instead, highlight some key points that are relevant here. Schmitter (2001, pp 67-89), contributing to the debate on party crisis / decline, remarks that 'parties are not what they once were'. Though he acknowledges the central role they play in the consolidation of democracies, he warns that students of contemporary political parties tend to ignore the changes taking place in their nature and role in established democracies, or expect contemporary parties to play the same roles as those in the 19th century.

Despite a failure to acknowledge the diversity found within the study of parties today, Schmitter (2001, p 71) has succeeded in contributing to the debate, perhaps in order to strengthen further the role of parties and improve the nature of governance in democracies. He emphasises that the emergence of intermediary agents, which are more organised, specialised and professional than party organisations, and the effects of the international environment, are providing political parties with competition from diverse interest, associations and social movements, which are struggling to perform similar political functions in the consolidation of neodemocracies (emphasis in the original). But he also states (2001, $\mathrm{p} 71$ ) that 'I am not claiming that political parties do not make some contributions to the consolidation of democracy and I am certainly not predicting that they will somehow fade away in neodemocracies.'

However, the relevance for this paper is that, while acknowledging these challenges, we can also see that political parties are undergoing transformation and embracing the new challenges posed by the rapidly changing local and international environment in which they operate. In established democracies parties face the changing demands of citizens, a wide spectrum of public policies, and the shifting role of the state in economic development. They are facing a vibrant civil society, an independent press, and a global network, with its attendant challenges.

In new democracies, especially in Africa, parties are facing the challenges of formulating and implementing policies that address the issues of deprivation, environmental alienation, poverty, disease (HIV / AIDS, maternal death, etc) and social exclusion and, most importantly, crises of legitimacy in states where elections were not free and fair and not seen as such; where the press is not free; and where freedom of information and speech are undermined. Internally, parties are facing challenges of discipline, ideology, inter- and intra-party conflict and lack of adequate resources, all of which affect their functioning. Montero \& Gunther (2002, p 1) eloquently capture the debate when they maintain that scholars have been: 
led to dismiss further empirical study of parties on the grounds that parties are becoming increasingly irrelevant, since they are failing to respond successfully to a series of challenges, and many of their functions are performed better by less formally organised social movements, by direct contact between politicians and citizens through the broadcast media or the internet, or by innovations in direct democracy. In the view of this group of scholars, parties may be seen as in an inexorable process of 'decline'. Finally, there may be some who have concluded scholarly research on parties has failed to advance the task of developing rigorous and persuasive theory, and that further efforts along these lines are doomed to fail.

Three factors can be deduced from the above observation, through which scholars argue against further research and / or the decline of political parties. The first is the failure of parties to respond to and/or contain contemporary challenges in the areas of communication, funding, and so on. Secondly, other informal groups are performing many of the functions of political parties such as political education and mobilisation, linkage, integration, and so on. Thirdly, there is no rigorous theory of political parties despite more than a century of research. Thus, from a broader perspective, the study of political parties is even more justified than it has been hitherto, especially under the banner of representative democracy. Montero \& Gunther (2002, pp 1-2) conclude that the continuing importance of parties in all representative democratic systems and the contemporary global challenges confronting parties call for more rigorous and intensive empirical research. This, therefore, makes it dramatically important to thrust 'towards the formulation and systematic testing of more sophisticated and empirically grounded hypotheses with the ultimate objective of developing a more compelling set of middle-range theories' (Montero \& Gunther 2002, p 2).

Mair (2006, p 2) stresses that as a result of changes in the character of democracy, changes in the society under which parties operate, and changes within the parties themselves, parties are finding it difficult to perform their representational functions and still remain firm on procedural functions. He concludes that perhaps the only way parties can assure themselves of a future is by facing up to the new challenges forced by structural changes and by accepting the real circumstances (ie, that there is little prospect of building strong party roots within society and no prospect of maintaining a distinct and powerful organisational identity based on ideology), and by concentrating on institutionalising their legitimacy as catalysts of a form of democracy that is inclusive, transparent, and accountable, that is, democratic good governance.

This projection of the changing nature of political parties might be a source of 
relief to scholars and students of African political parties who are waiting anxiously to see parties in new democracies resemble their counterparts in developed democracies, especially those of 19th-century Western Europe and America. This also means that the criteria for measuring party institutionalisation, as suggested by Randall \& Svåsand (2001), and party system institutionalisation by Mainwaring \& Scully (1995) need to be re-evaluated at least to reflect the inevitable changes introduced in the world of political parties.

It can also be argued that the idea of the crisis and the critical era of political parties (Aldrich 1997, pp 2-25) is one of the three theoretical myths about parties and democracy. Mainwaring (2001) stresses that changes to parties as a result of the communication revolution do not necessarily signify their downfall. In fact, political parties remain even stronger today in industrial democracies than in new democracies. Based on experiences in Latin America, he reasons that strong parties are not essential for democracy, but a well-institutionalised party system is a sine qua non for lasting democracy. One can add that for a reasonably institutionalised party system to flourish individual party institutionalisation is a prerequisite as it eliminates those parties that have no realistic chance of winning any elections and therefore are associations or movement in disguise, or forces them to merge or collaborate with major parties (Schmitter 2001, p 71).

As pointed out above, the changing circumstances of political parties in the developed world is sending a signal to emerging democracies, and this has implications for the life and functions of parties in this region. Be that as it may, a serious rethink is necessary about the future of political parties vis-à-vis democracy in Africa. In particular, it raises questions for existing theories about the role of political parties in complex pluralistic states in Africa, the importance of party systems and party institutionalisation, the question of public and private funding of political parties, the question of decentralisation, the structural organisation and the relationships between political parties and rapidly growing civil society organisations.

\section{THE DEVELOPMENT OF POLITICAL PARTIES IN AFRICA}

An understanding of the historical trajectories of the development of African political parties is crucial to appreciating and analysing the current nature of the parties and the variety of problems that besieged them in the democratisation project. This section sets out to provide that. The political history of Africa in the 19th century is one of colonial rule and imperialism, followed, in the 1950s and 1960s, by struggles for liberation and independence. Different kinds of decolonisation movements and nationalist organisations were formed as catalysts for the struggles. Immediately after independence, parties were formed, based 
on ethnic and regional lines. This had severe and lasting effects on the development of political parties and party politics in Africa. Sklar $(1967, \mathrm{p} 6)$ stresses that:

Each party secured its power in a region of the country by appealing to ethnic sensibilities, among other means. Under a federal system of government, each party was able to consolidate its power by exploiting regional government resources. Privileged class interests, entrenched in the regions, have been opposed to any fundamental transformation of the regional power system. Time and again, they have been willing to perpetrate electoral fraud at the risk of violence and secession in order to prevent radical political changes. Tribalism has been their trustworthy weapon against change.

According to Mboya (1957) many national trade unions metamorphosed into nationalist organisations and eventually became political parties. And in other countries peasant farmers organised against colonial agricultural policies. Syndicat Africain Agricole in Côte d'Ivoire was one such organisation (Morgenthau 1964). These nationalist organisations, characterised to some extent by primordial and sectional interests 'lacking both ideology and organisational capacity that could bind conflicting interests together in the post-independence period', metamorphosed into political parties (Nyong'o 1997, p 7). The succeeding political parties exploited state political and administrative powers as instruments for political mobilisation and control, hence the emergence of one-party dictatorships. Thus, parties became instruments for political control for selfish ends rather than mass movements for the mobilisation of citizens for popular participation in and institutionalisation of democratic governance (Nyong'o 1987). People from the leaders' ethnic group usually fill the parties' administrative offices.

The Benin People's Revolutionary Party (PRPB) and the Dehomeyan Democratic Party (PDD) in Benin, the Kenya African Democratic party (Kanu), the Tanganyika African National Union (Tanu), the United National Independence Party (UNIP) in Zambia, the Democratic Party of Guinea (PDGuinea), the Popular Movement of the Revolution (MPR) in former Zaire, the Democratic Party of Côte d'Ivoire-African Democratic Party (PDCI-RDA), Mugabe's Zimbabwe African National Union-Patriotic Front (Zanu-PF), the Voltaic Democratic Union-African Democratic Rally (UDV-RDA) in Burkina Faso, the Cameroonian National Union-Cameroon People's Democratic Movement (UNC/RPDC), the Chadian Progressive Party (PPT), the Convention People's Party (CCP) in Ghana, the Committee of Togolese Unity (CUT), the Ugandan People's Congress (UPC), the Sudanese Union-African Democratic Rally (US-RDA), the Mali People's Democratic Union (UDPM), the Senegalese Progressive Union(UPS), and so on, have represented both de jure and de facto one-party systems in Africa. 
One-party systems, military dictatorships and military coups have characterised political party development in Africa, with economic development, unity, and integration overcoming instability and corruption advanced as reasons for such developments. Malawi, Angola, Mozambique, Tanzania, Zambia and Zimbabwe were examples of de jure one-party dictatorships; Kenya and Lesotho, among others, had de facto one-party systems and Nigeria, Ghana, Burkina Faso, Niger Republic and Benin were examples of countries where military dictatorships obstructed the development of multi-party democracy. In Kenya, until the repeal of the Constitution (Section 2A) in 1991, the country had been under the dictatorial dominance of Kanu, exhibiting all the basic traits of authoritarianism (CDG Policy Brief 2005). It was only after 1991 that Kanu permitted the creation of opposition parties. However, given the long period of political dominance of Kanu and the absence of any viable opposition, the new parties could not challenge the organisational authority of the party.

Three different scenarios could be discerned from the development of political parties in Africa: parties established before independence; parties that emerged from liberation movements; and parties established by military regimes (Salih 2003).

Many political parties in Africa were founded during colonial rule and used as instruments of struggle for political independence. This was most apparent in countries that achieved their independence through constitutional engineering, albeit by peaceful means. Examples of these include Nigeria, Ghana, Sierra Leone and other British colonial states. While in some countries military coups and civil wars terminated the 'life' of most of these 'colonial parties', in others many have survived and persist. In the latter, the colonial parties, especially the ruling parties, metamorphosed into one-party systems either through systematic but illegal elimination of opposition parties or through smaller parties going into electoral alliances with the ruling parties as the only means of survival. It is important to note here that some political parties still 'managed to maintain some measure of continuity' (Salih 2003, p 9).

Political parties were established by the military in countries which experienced a series of military takeovers and where the original colonial parties were dismantled. It is a tradition of the military that whenever they intervene in political affairs they first suspend the constitution, and then ban all political activities and all existing political parties and organisations and rule by decree. By implication, democratisation is abruptly obstructed and suspended. Whenever, the temporary political euphoria, support, and popularity enjoyed by the leaders of a coup wane, domestic civil society and the international community combine to pressurise the military to return the country to democracy. Accordingly, military regimes 'become unpopular as a result of their failure to deliver on their promise, 
indulgence in corruption capitalising on the lack of checks and balances of their authority' (Salih 2003, p. 19).

When returning their countries to a democratic path military regimes in Africa, and perhaps elsewhere, embark on a programme of transition to civilian rule through which a new constitution is promulgated, electoral organisation are established and politicians are mandated to create political parties strictly in accordance with military decrees guiding their formation and activities. By means of this process, military regimes become the architects of political party formation. New political parties are established and old ones thrown into the dustbins of history. This situation has critically affected the continued existence of political parties in Nigeria, Ghana, Niger, Sudan, and a host of others. However, of all the African states that have experienced military regimes Nigeria provides the most awful example.

In Nigeria the first military coup was staged in January 1966 after just five years of independence. From 1967 to 1970 the country was enveloped in a bloody civil war. The military regime lasted until 1979 when the country returned to democratic rule. Four years later, in December 1983, the military struck again and continued to rule until 1999. In both 1979 and 1999 political party formation and activities were anchored by military decrees. Political associations had to fulfil stringent and cumbersome criteria before they were officially allowed to participate in the democratisation process. What was even more politically awkward was the attempt, in 1993, by the Babangida regime not only to sanction the formation and activities of political parties but to impose two state-sponsored political parties: the Social Democratic Party (SDP) and the National Republican Convention (NRC).

The state created the parties, provided their respective constitutions and manifestoes, built their national, state and local government secretariats, appointed their principal officers and, above all, 'ordered' politicians to join the parties. The state also paid all the expenses of the parties, including financing their members attending congresses and conventions. What the Nigerian example, like those in Sudan and elsewhere, indicated, was that parties established by the military are not people's parties. It is politicians, as custodian of party politics, who should be allowed to create and sustain political parties.

The third major element in the development of African political parties is liberation movements which metamorphosed into political parties. Many colonial entities achieved independence through the establishment of formidable movements that forcibly conditioned colonial masters to grant independence and which, either in the course of or after the formal declaration of independence, transformed into political parties. Examples include the Popular Movement for the Liberation of Angola (MPLA), the National Front for the Liberation of Angola 
(FNLA) and the National Union for the Total Independence of Angola (Unita); the Mozambique Liberation Front (Frelimo) and the Mozambican National Resistance (Renamo); the South West Africa People's Organisation (Swapo) in Namibia, the African National Congress (ANC) in South Africa, and Zanu-PF in Zimbabwe.

It is beyond the scope of this paper to detail the development of these liberation organisations and the process of their metamorphosis into political parties. What should be emphasised, though, is that many, if not all these parties have continued to rule their respective countries since independence. Thus, the liberation political parties exhibit all the traits of one-party systems. They are populist parties that have tried to show that they are democratic, but, in reality, it is difficult to distinguish them from the governments they established (Salih 2003). Like other African political parties they are often beset by sectionalism and ethnicity and advance themselves through neo-patrimonialism (a modern form of patrimonialism, characterised by rational-legal procedures clouded by personalistic ties and patronage), clientalism and violence.

Despite intermittent terminations of political parties, especially by military regimes, civil wars and through the co-option of smaller parties by dominant ones, many political parties were able to withstand these problems and persist today. Table 1 highlights some of the longest-surviving parties in Africa. These parties, apart from those in a few 'free' or liberal democracies, have not acquired the democratic features necessary for institutionalisation. The fact that they have survived does not in any way mean that they have satisfied the criteria for institutionalisation.

Beyond these political legacies the reintroduction of multiparty democracy in Africa during the third and fourth waves (ie, after the collapse of communism and the end of the Cold War) was a good omen for interaction and democratic development. However, the slapdash nature of such transformation, without credible constitutional, legal, political and administrative reforms has largely caused the enormous problems that today besiege the development of multiparty democracy.

Stakeholders in the democratic project, particularly civil society, the legal system, the legislature and the political parties, entered the new political atmosphere ill prepared and ill organised. Coupled with this were fresh political, administrative and organisational quagmires. Some parties have, therefore, remained avenues for advancing individual and selfish group interests and organisations in which political elites continue to dominate economic and political systems in various countries. Most significantly, the reintroduction of multiparty democracy in Africa has led to the erosion of single-party systems. These have been replaced by dominant-party and two-party coalition systems (Salih 2003, $\mathrm{p} 7$ ). This scenario has affected the development of competitive political parties. 
Table 1

Longest-Serving Political Parties in Africa

\begin{tabular}{|c|c|}
\hline Party & Duration \\
\hline MPLA, Angola & $\begin{array}{l}1975 \text { to date and adopted multiparty } \\
\text { democracy in } 1992\end{array}$ \\
\hline Botswana Democratic Party (BDP) & From independence in 1966 to date \\
\hline Cameroon People's Democratic Movement (CPDM) & $\begin{array}{l}\text { From } 1960 \text { and returned to multiparty } \\
\text { democracy in } 1992\end{array}$ \\
\hline People's Rally for Progress (RPP), Djibouti & $\begin{array}{l}1977 \text { to date and adopted multiparty } \\
\text { democracy in } 1992\end{array}$ \\
\hline Workers' Party of Ethiopia (WPE) & 1974 to 1991 \\
\hline Kanu, Kenya & $\begin{array}{l}1963 \text { to date and adopted multiparty } \\
\text { democracy in } 1992\end{array}$ \\
\hline Malawi Congress Party (MCP) & 1964 to 1994 \\
\hline UDPM, Mali & $\begin{array}{l}\text { 1960-1991. Military coup brought about } \\
\text { democracy in } 1992\end{array}$ \\
\hline Frelimo, Mozambique & $\begin{array}{l}1975 \text { to date and adopted multiparty } \\
\text { democracy in } 1994\end{array}$ \\
\hline Swapo, Namibia & 1990 to date \\
\hline $\begin{array}{l}\text { National Movement for a Developing Society } \\
\text { (MNSD), Niger }\end{array}$ & $\begin{array}{l}\text { 1960-1993. Military regime returned } \\
\text { democracy in } 1996\end{array}$ \\
\hline SP, Senegal & $\begin{array}{l}\text { 1964-98. Introduced controlled competitive } \\
\text { democracy in } 1974\end{array}$ \\
\hline Seychelles People's Progressive Front (SPPF) & $\begin{array}{l}1976 \text { to date and adopted multiparty } \\
\text { democracy } 1996\end{array}$ \\
\hline Sierra Leone People's Party (SLPP) & $\begin{array}{l}1961 \text { to date. Interrupted by series of military } \\
\text { coups }\end{array}$ \\
\hline Sudanese Socialist Union (SSU) & 1971-1985 \\
\hline Tanu, Tanzania & 1961-1990 Succeeded by CCM \\
\hline RPT, Togo & 1970 to date \\
\hline UNIP, Zambia & $\begin{array}{l}\text { Since } 1964 \text { and returned to multiparty } \\
\text { democracy in } 1991\end{array}$ \\
\hline ZANU-PF & $\begin{array}{l}1980 \text { to date and returned to multiparty } \\
\text { democracy in } 1992\end{array}$ \\
\hline
\end{tabular}

Source: Salih (2003) 
In Africa political parties did not emerge as a rational choice for resolving societal, political and economic policy issues, nor were they established for proper state coordination (see Aldrich 1995; Cox \& McCubbins 1993). Parties emerged to create the political system instead of the reverse, which is the case in more established democracies. In advanced democracies 'the development of parties seems bound up with that of democracy that is to say with the extension of popular suffrage and parliamentary prerogatives' (Duverger 1954 pp xxiii-iv).

The high degree of economic underdevelopment and social decay in Africa has also affected the development of political parties on the continent. Parties were created at a time when Africa was struggling with fundamental economic problems. States continue to face economic crises with increasing social hardship for citizens, a factor which contracts the political space with parties finding it increasingly difficult to participate. The economic situation has also bred enmity among political elites and social groups, culminating in a series of civil wars. From Liberia to Algeria, from Ethiopia via Somalia to Rwanda, Côte d'Ivoire to Nigeria, the story is the same. Virtually all African countries have at one time or another experienced protracted civil strife and/or political instability. Political crises and economic underdevelopment have had devastating consequences for party development and for the institutionalisation of parties and party systems.

Given the nature of the emergence of political parties and the way they were used by African elites to institutionalise authoritarian rule, Mozaffar \& Scarrit (2005, p 400) stress that the roles of parties in Africa were either proscribed or limited. The structure of African political systems is characterised by 'dominant party systems with low levels of electoral and legislative competitiveness, low levels of fragmentation and high degrees of disproportionality'.

The African party system therefore, according to Mozaffar et al (2003), reflects a combination of low fragmentation and high volatility. This is related largely to the character of electoral institutions and the salience of ethno-religious groups. Mozaffar \& Scarrit (2005, pp 416-17) further contend that the 'puzzling combination of low party system fragmentation and high volatility' is explained by the significance of strategic calculation in the formation and development of political parties and the institutional legacies of colonial rule of authoritarian regimes established after independence. The result, they conclude, is that in analytical terms the individual political party is less important in the consolidation of 'third-wave' democracies. But they agreed that an effective party system is crucial to democratic consolidation.

Furthermore, they note that the puzzling character of the African party system is conducive to democratic consolidation, a finding that contradicts the popular view that ethnicity and sectional interests are the bane of African political parties. Mozzaffar \& Scarrit (2005, p 416) contend that: 
Because of the political salience of ethnicity [religion, sectional and primordial values] as ... important source[s] of strategic coordination, and because no African-political group is numerically large enough to form either a political party or a government on its own, multiethnic [and religious] coalitions tend to be the norm in the formation of political parties as well as in the formation of governing [and/or electoral] coalitions.

It is important in any analysis of African political parties to appreciate the role of economic development, the effectiveness of the electoral system, the nature of civic culture, the continued existence of previously dominant parties, and the degree of social cohesion of individual countries. It is unfortunate that many studies of African political parties are silent about the civic culture and social cohesion of the societies. African political parties must therefore be distinguished by their context: colonial heritage, economic dependence and underdevelopment; the salience of ethnicity and primordial values; the weakness of civil society, patrimonialism, and the structure of the state and other institutions (Randall 1988; Randall \& Svåsand 2001; Carey 2001; Mozaffar et al 2003; Mozaffar \& Scarrit 2005).

Another feature of the development of political parties in Africa is the military interregnums. Military elites hold the key to the 'life and death' of political parties. They create political parties and disband them at will. Randall (1988, p 3) emphasises that 'while party regimes have regularly been overturned by military coups, these same military regimes almost as regularly, and sometimes after quite a short interval, have either reinstated some form of party politics or actually returned government to party politicians'.

In this kind of situation even an uncritical observer would accept that military rule has contributed to thwarting political party development and especially party and party system institutionalisation in Third World countries such as Pakistan, Sudan, Brazil, Nigeria, Liberia, Ghana, Niger, Turkey, Chad, Congo (Brazzaville and Kinshasa), Rwanda, Somali, Ethiopia, and so on.

Interestingly, despite the apparent institutional, organisational, and situational problems that obstructed the development and institutionalisation of party and party systems in Africa, in some states political parties have endured since their inception. In these countries the development of parties has been 'both more complex and more fluid: parties wax and wane, disappear and return but [still remain fundamentally] an enduring element in the political formulae of Third World states [perhaps because democracy can't do without them]' (Randall 1988, p 175). Such countries include Botswana, Mauritius, the Gambia, Ghana and São Tome (see Table 2). These examples perhaps prove that political parties 
and democratic governance can be successfully 'transplanted' and institutionalised in the whole of Africa.

It is also important to stress that the transformation of the political system has seen political parties proliferate in a manner never recorded in the history of Africa. The number of parties capable of participating in general elections ranges from four to sixty (see Table 2).

Table 2

Number of Parties Participating in Legislative Elections*, Freedom Ratings and Regime Type in Africa

\begin{tabular}{|l|c|c|l|l|}
\hline Country & $\begin{array}{l}\text { Date of } \\
\text { last election }\end{array}$ & $\begin{array}{l}\text { No of } \\
\text { parties }\end{array}$ & $\begin{array}{l}\text { 2006 Freedom } \\
\text { ratings }\end{array}$ & Regime type \\
\hline Angola & 1992 & 18 & Not free & Electoral autocracy \\
\hline Benin & 2003 & 35 & Free & Oscillating democracy \\
\hline Botswana & 2004 & 7 & Free & Liberal democracy \\
\hline Burkina Faso & 2002 & 30 & Partly free & Electoral autocracy \\
\hline Burundi & 2005 & 6 & Partly free & Electoral autocracy \\
\hline Cameroon & 2002 & 42 & Free & Electoral autocracy \\
\hline Cape Verde & 2006 & 05 & Free & Liberal democracy \\
\hline Central African Republic & 2005 & 29 & Partly free & Electoral autocracy \\
\hline Chad & 2002 & 42 & Not Free & Electoral autocracy \\
\hline Comoros & 2004 & 10 & Partly free & Electoral autocracy \\
\hline Republic of Congo & 2002 & 100 & Not Free & Electoral autocracy \\
\hline Côte d'Ivoire & 2000 & 10 & Not Free & Electoral autocracy \\
\hline Djibouti & 2003 & 08 & Partly Free & Electoral autocracy \\
\hline Equatorial Guinea & 2004 & 13 & Not Free & Electoral autocracy \\
\hline Ethiopia & 2005 & 50 & Partly free & Electoral autocracy \\
\hline Gabon & 2001 & 36 & Partly free & Electoral autocracy \\
\hline Gambia & 2002 & 18 & Not Free & Electoral autocracy \\
\hline Ghana & 062 & Partly free & Electoral democracy \\
\hline Guinea & 40 & Partly free & Electoral autocracy \\
\hline Guinea Bissau & 2004 & Free & Electoral democracy \\
\hline Kenya & 11 & Partly free & Electoral autocracy \\
\hline
\end{tabular}




\begin{tabular}{|c|c|c|c|c|}
\hline Lesotho & 2002 & 19 & Free & Electoral democracy \\
\hline Liberia & 2005 & 17 & Partly free & Electoral autocracy \\
\hline Madagascar & 2002 & 41 & Partly free & Electoral democracy \\
\hline Malawi & 2004 & 11 & Partly free & Electoral democracy \\
\hline Mali & 2002 & 12 & Free & Electoral democracy \\
\hline Mauritania & 2001 & 16 & Partly free & Electoral autocracy \\
\hline Mauritius & 2005 & 20 & Free & Liberal democracy \\
\hline Mozambique & 2004 & 15 & Partly free & Electoral democracy \\
\hline Namibia & 2004 & 08 & Free & Electoral democracy \\
\hline Niger & 2004 & 19 & Partly free & Electoral autocracy \\
\hline Nigeria & 2003 & 30 & Partly Free & Electoral autocracy \\
\hline Sõo Tome \& Principe & 2006 & 09 & Free & Liberal democracy \\
\hline Senegal & 2001 & 61 & Free & Electoral democracy \\
\hline Seychelles & 2002 & 04 & Partly free & Electoral democracy \\
\hline Sierra Leone & 2002 & 10 & Partly free & Electoral autocracy \\
\hline South Africa & 2004 & 16 & Free & Liberal democracy \\
\hline Sudan & 2000 & 08 & Not Free & Electoral autocracy \\
\hline Swaziland & 1998 & *** & Not Free & Electoral autocracy \\
\hline Tanzania & 2005 & 13 & Partly free & Electoral autocracy \\
\hline Togo & 2002 & 25 & Not Free & Electoral autocracy \\
\hline Uganda & 2006 & 10 & Partly free & Electoral autocracy \\
\hline Zambia & 2001 & 15 & Partly free & Electoral autocracy \\
\hline Zimbabwe & 2005 & 07 & Not Free & Electoral autocracy \\
\hline Rwanda & 2003 & 08 & Not Free & Electoral autocracy \\
\hline Eritrea & $1993^{* *}$ & 01 & Not Free & Electoral autocracy \\
\hline Congo-Brazzaville & 2002 & 05 & Partly free & Electoral autocracy \\
\hline Burundi & 2005 & 21 & Partly free & Electoral autocracy \\
\hline
\end{tabular}

Source: Compiled from Lindberg (2006); Freedom House Survey (2006) and 'African Election Data: A Database for Election Results in Sub-Saharan Africa', <http:/ / africanelections.tripod.com/index.html>, July 2006

* This does not include small parties that are not capable of participating in parliamentary elections

** Since independence the country has not held national elections and has only one political party, the PFDJ

*** Non-party National Assembly election was conducted in 1998 - 55 members elected and 10 nominated by the King. 
Table 2 shows that the proliferation of political parties and the expansion of the political space have not deepened democratisation in Africa or improved the quality of governance, nor does it ensure peaceful political participation and alternation of power, critical components of democratic consolidation. The table further indicates that the proliferation of political parties, especially during the third and fourth waves of democratisation, did not guarantee the expansion of political rights and civil liberties.

Democracy is still in its infancy in many African countries. The table further depicts the contradictory nature of African democratisation. While the post-Cold War period has seen burgeoning numbers of political parties and civil society organisations and the widening of political space, this development has not led to a greater spread of political rights and civil liberties. At most, therefore, only a few countries in Africa qualify as liberal democracies with a Freedom House 2006 score of 2.0 on political rights and civil liberties and elections judged to be free and fair by domestic and international standards. Only nine states were judged to be electoral democracies which hold relatively free and fair elections but do not meet the standard of provision of political rights and civil liberties.

In other words, electoral democracies scored below average on Freedom House's scale of political rights and civil liberties and the majority of African states fall into the category of what Lindberg (2006) describes as 'electoral autocracies'. These are countries that conduct elections only as a basic requirement and a mere formality (ie, elections are largely flawed), but do not meet the criteria for either electoral or liberal democracies (see Lindberg 2006, pp123-38). What is even more revealing is that of all the African countries included in the Freedom House survey only 11 were considered 'free' by global standards. This means that more than two-thirds are either 'partly free' or 'not free' at all. Countries falling into these categories are likely to degenerate into dictatorships or be liable for military takeover. In the 'free' countries, democracy has not only come to stay but is accepted as the 'only game in town' (Linz \& Stepan 1996, p 1) and as 'a settled way of life' (Pickles 1970, p 57).

From the above it is clear that there are many dimensions to the transformations being experienced by political parties in Africa. However, one of the challenging scenarios is the perpetuation and entrenchment of a 'dominant-party system'. Bogaards (2004, pp 173-97), applying Giovani Sartori's classic counting formulae, party system typology and definition of a dominant party, argues that in African democracies 'one party has an absolute majority of seats in the legislature and can govern alone' or two parties enter into an electoral coalition (see Table 3). Indeed, this phenomenon seems to be widespread, an indication, perhaps, that Africa may be returning, albeit with some differences, to the political dictatorship of the 1970s and 1980s. 
More than 20 emerging African democracies are exhibiting this tendency. Ironically, even some models of stable democracy in Africa, such as Botswana, are caught in this dilemma. This is certainly part of the crisis of transformation that is besieging political parties in Africa. This trend 'suggests an urgent need for systematic research into the nature, sources, conditions and consequences of dominant party systems in Africa' (Bogaards 2004, p 192). The plain truth is that the one-party dominance scenario in Africa is a dangerous trend that can certainly spell doom for domestic and international efforts at re-democratisation. It is even more dangerous as the domestic civil societies are, as a result of both commission and omission, being emasculated and silenced. Currently ruling parties are employing all necessary extra-democratic measure to curtail opposition. ${ }^{3}$

\section{CLASSIFYING AFRICAN POLITICAL PARTIES}

Within the universal typologies of political parties African parties, by the nature of their activities, the exclusive pattern of the way they function, and the character of the socio-political and economic context in which they operate, are unique. Literature on the classification of political parties worldwide is rich (Kirchheimer 1966; Neumann 1956; Duverger 1954; Katz \& Mair 1995; Puhle 2002; Kitschelt 1989 and 1994; Wolinetz 2002; Panebianco 1988 and many others too numerous to mention). It is also a fact that categorisations of political parties in early studies have become outdated, as most of the studies did not involve parties that emerged during the third and fourth waves of democratisation. The impact of social and technological revolutions on the activities of parties, on one hand, and the need to re-evaluate the current party models, concepts, and terminologies, on the other, have led Diamond \& Gunther (2001 \& 2003) to create the 'species' or 'typologies' of modern political parties. The party typologies offered by Diamond \& Gunther provide the most comprehensive and scientific classification of contemporary worldwide political parties. They not only capture the socio-political and economic circumstances of countries but may also be used for 'hypothesis-testing and theory building'.

The three criteria of (i) the nature of the formal organisation of parties (ii) the nature of the parties' programmatic commitments, and (iii) the strategy and behavioural norms of parties and the sociological and internal dynamics of party decision-making were employed in constructing ideal new models of political parties. Accordingly, 15 classifications of parties around the world, cutting across

3 The arrest and trial of Dr Kizza Besigye in Uganda, the leader and presidential candidate of the main opposition party (FDC) for alleged terrorism and rape, is a testimony to how opposition parties are denied free participation in the political process in Africa. 
space and time, were identified. These 15 were categorised in five broad groups and reflect the real world of political parties (see Diamond \& Gunther 2001 and 2003). See Figure 1.

Figure 1

Classification of Political Parties

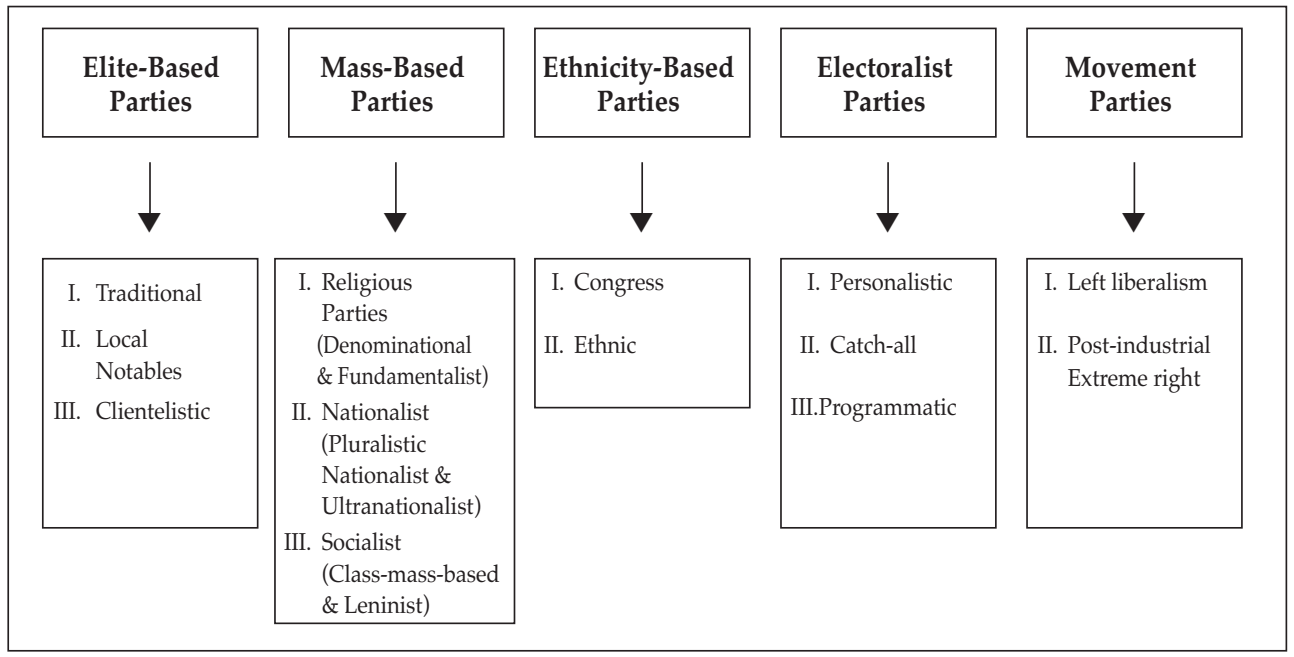

Source: Diamond \& Gunther 2001

The classification in Figure 1 is based on the organisation and nature of parties in previous centuries and modern political parties in operation today. They are classified into organisationally thin (elite, electoralist, movement and ethnicallybased parties) and organisationally thick (mass-based) parties. The broad and elaborate classification of political parties by Diamond \& Gunther, although explicit enough to capture the varieties of parties that are currently operating creates difficulties when some parties display characteristics of more than one party type.

Most of these parties, especially those formed haphazardly to get rid of authoritarian or military regimes, are found in the African democracies. There are today dozens of political parties in Africa, many of which are new, some of which are new embodiments of old parties, and others which have a long history (Burnell \& Randall 2004). These parties tend to exhibit weak party institutionalisation, a complex and/or poor organisational framework, and the tendency to serve the interest of the elite for personal aggrandisement. Diamond \& Gunther (see Figure 1) have presented five broad categories of political parties based on distinguishing organisational features and in each there are further subcategories based on the ideology and strategic orientation of the parties. 
They suggest that the 'genus' of elite and mass-based parties and their 'species' typifies the kind of parties that existed in the course of the development of democracy in the early 19th through the 20th centuries in Europe and America, with few elsewhere. However, according to this typology, African political parties were classified as ethnic, electoralist and movement parties. These generally emerged from the middle to the end of the 20th century, and beyond (see the discussion above of the three scenarios of the development of political parties in Africa). What these typologies indicate is that despite quantitative transformation African political parties are most weakly institutionalised and will perhaps take much longer to transform than political parties elsewhere, especially in Latin America. Many are permeated by ethnic cleavages, serving the primordial and clientelistic aspirations of the political elites that established them and, more often, are used as instruments of criminalising social and political order. The nature of African political parties not only affected their democratic activities but, importantly, affected the quality of democratic governance and development of sustainable democracy which they aspire to engender.

\section{Party Institutionalisation and the Sustainability of Democracy}

Conceptually, institutionalisation is about institutions, processes and outcomes. It is about establishing functional institutions within the boundaries of the law and working, also within the limits of the law, for efficiency and effectiveness. Amundsen (2001, p 52) argues that institutionalisation means building institutions and making them work efficiently in a rational-bureaucratic manner. Indeed, building institutions and ensuring that they work effectively and efficiently and produce the desired outcomes involves serious 'ups' and 'downs'. Institutionalisation is thus an endless process. Perhaps this is why it is a matter of degree. Political party institutionalisation, therefore, connotes the degree to which parties as an institutional component of democracy conduct their activities and discharge their functions, efficiently and effectively, in accordance with the overall constitution of the society, the constitution and informal rule of the parties, the rules governing elections, and international norms and conventions governing the game of politicking and contest for power.

Political parties, functioning within these parameters, would presumably attain what Huntington (1968, p 12) called 'value and stability', as defining characteristics of institutionalisation. Democratic values and stability are important elements for understanding the nature and character of a political party and how that influences the 'rational-bureaucratic' activities of the party. Panebianco (1988, p 53), using a rational choice model, stresses that 'institutionalisation is the process by which an organisation incorporates its founders' 
values and aims. The organisation slowly loses its character as a tool: it becomes valuable in and of itself, and its goals become inseparable and indistinguishable from it. In this way, its preservation and survival become a "goal" for a great number of its supporters.'

From these theoretical concepts, it is clear that party institutionalisation is a process by which the party acquires stable values, norms, procedures, and routines by encapsulating its members' interests in the overall interests of the society within which it operates and which it aspires to develop and sustain. Achieving institutionalisation is a question of the nature and character of the economic system and the socio-political and cultural terrain in which the political party(ies) operate. In other words, the nature of the political economy and socio-political landscape of the state influence the process of the party's institutionalisation.

Using these concepts of institutionalisation and, especially, adopting Randall \& Svåsand's (2001) external-internal and structural-attitudinal model of party institutionalisation, and Mainwaring \& Scully's (1995) criteria for party-system institutionalisation, contemporary African political parties are not institutionalised. Meanwhile, according to Mainwaring \& Scully (1995, p 1):

an institutionalised party system implies stability in inter-party competition, the existence of parties that have somewhat stable roots in society, acceptance of parties and elections as the legitimate institutions that determine who governs, and party organisations with reasonably stable rules and structures.

African political parties are not institutionalised, perhaps because neither individual parties nor party systems has met these criteria. But it is also important to emphasise that despite this there are marked variations in the extent to which each party and party system is in the process of institutionalisation. The variations further reveal why dominant-party systems are emerging on the continent.

Given the critical functions of political parties in a democratic project, democracy can be inaugurated without institutionalised parties and party systems. In other words, the inauguration of democracy does not require institutionalised parties or party systems. But the development of sustainable and stable democratisation is certainly and absolutely a function of such institutionalisation. The evidence from and experiences of both underdeveloped and developed democracies clearly support this assumption.

With the return of democracy in Africa and the establishment and reestablishment of political parties, the ultimate goal of individual countries is to sustain the democratic project for political stability and economic development. Democratic sustainability is a function of many institutions of democracy itself, 
such as electoral institutions, the legislature, the executive, civil society, civil society organisations and, to a very great extent, the international community. Amundsen (2001, p 52) argues that democratic sustainability simply implies that the core democratic institutions, political parties, media, and civil society organisations are 'well organised and operating efficiently in a rational-bureaucratic sense'. He also maintains that the concept implies that all major players accept the democratic rules of the political game, so that political competition takes place within, but is not about, the institutions of democratic government.

Indeed, democratic sustainability suggests that these institutions must be stable, acquire values, and play the game according to the stipulated rules, be they constitution, statutes or informal regulations. In this political parties play a central and pivotal role. This is, perhaps, why Gentili (2005, p 2) contends 'no democracy no party, no parties no democracy' and democracy, according to Schattschneider (1942), is simply 'unthinkable save in terms of political parties'. In sum, political party institutionalisation is the most critical factor in the consolidation and development of sustainable democracy, although other factors such as free and fair elections, a credible judicial system that ensures the rule of law, and accountability and transparency are also vital.

This argument is premised on the consideration that political parties are 'essential instruments for representing political constituencies and interests, aggregating demands and preferences, recruiting and socialising new candidates for office, organising the electoral competition for power, crafting policy alternatives, setting the policy-making agenda, forming effective governments, and integrating groups and individuals into the democratic process' (Diamond 1997, p xxiii). Furthermore, political parties craft and re-craft constitutions and major laws and procedures of the state, manage the state apparatuses, and provide the general framework for political and economic society and the establishment of the rule of law; they interact with civil society and act as a link between it and the state (Van Biezen 2003, p 5).

To say that parties in African states are facing serious challenges in ensuring sustainable democracy is stating the obvious. However, institutionalisation of the parties is the first step towards achieving this goal. It is now clear that African political parties are going through a critical period of transformation clouded by situational problems and dilemmas. The above discussion assumes that the parties, however long they have existed, are not institutionalised.

By definition, transformation means marked positive changes in form and character. Political transformation, therefore, denotes political orientation and changes in values, norms, strategies and modes of acquiring power and governance networks. Broadly, transformation is a 'process that shapes the changing nature of political competition and cooperation through new 
combinations of concepts, capabilities, people and organisation (US Department of Defence 2003, p 3).

Transformation, therefore, is positive change accentuated by both internal and external forces. The re-democratisation of Africa, especially during its third and fourth waves, was made possible by internal pressure for liberty, freedom, participation, prosperous economic well-being, and international forces of globalisation, especially following the collapse of the communist regimes in Eastern Europe. ${ }^{4}$

This combination of forces led to a paradigm shift in the activities, nature and character of contemporary African political parties. As the parties are grappling with 'forced' changes, especially from within the political system itself, the nature of the socio-political and economic African states within which individual parties operate and function is not helping. Globalisation is further complicating the transformation process.

Today, citizens have direct access to information and need greater responsiveness, accountability, justice, equity and rule of law as well as more political space for participation and economic empowerment. This means that political party institutionalisation must be pursued simultaneously with the provision of these political and economic features.

In this context the challenges are enormous and the process increasingly difficult. This is perhaps why, in the process of institutionalisation, some parties may wane, some completely disappear, and there are mergers and political alliances. The political space might turn into a Darwinian environment, characterised by 'survival of the fittest'. The 'fittest' would be the strong, stable parties that would emerge at the end of the transformation period, and these are the institutionalised parties that will presumably sustain the democratisation process.

The duration of the period of institutionalisation differs from society to society, but is generally determined by the formation of the party, the strength of its organisational base and, above all, how it responds to major challenges. Nevertheless, it is worth noting that the gravity and intensity of these challenges differs from one state to another as do the responses and policy initiatives to resolve them. The major challenges are highlighted below.

4 Following the collapse of communist ideology and the ascendancy of liberal capitalism the relevance of ideology in political discourse seemed to wane. But in a society where, for several decades, dictatorship and economic underdevelopment (largely caused by lacked of visionary and patriotic leadership) held sway, the relevance of ideological and philosophical debate, especially in the struggle for power, remained important. Indeed, power contenders may profess the same capitalist liberalist ideology but the strategies and modus operandi of political consultations, public policy-making, service delivery and social redistribution may differ from party to party and it is through these and in several other ways that ideological differences would surface and thus the electorates would have a variety of choices. 


\section{Ideology}

Ideology is the systematic study of ideas. However, in view of the often loose usage of the term, it has been 'conceptualised in a number of ways, giving rise to a multiplicity of meanings and interpretations' (Dutt \& Mitra 2005, p 59). Adopting the views of Kau \& Rubin (1979) they argue that ideology connotes self-defined issues of public interest and the altruistic interests of politicians and political parties. Ideology, therefore, is an expression of the public interest and systematic ways of addressing that interest but it can also mislead or fool people, masquerade as public interest, and be used to serve narrow and unpopular interests.

It can, therefore, be both destructive and constructive depending on how it is employed in advancing popular aspirations. Political ideology, which is one of the defining differences between political parties, is conceived here to mean a body of ideas that epitomises the social and economic needs and aspirations of an individual, group, class or society. Broadly, it is a set of doctrines, a coherent system of ideas, beliefs and values that inform the political, economic and even social method(s) of societal organisation and governance.

Defined in this way ideology is one of the key factors differentiating political parties and political parties and other political groups. This is especially so because of the strategic role played by political parties in policy-making and implementation (ie, governance). The differences between the ideological orientation and persuasions of parties provide voters with a choice of how their interests should be provided for and protected. Underscoring the role of ideology in the process of institutional change and governance, North (1990, p 76) contends that:

Ideas and ideology matter, and institutions play a major role in determining just how much they matter. Ideas and ideologies shape the subjective mental constructs that individuals use to interpret the world around them and make choices ... people's perceptions that the structures of rules of the system is fair and just reduces costs; equally, their perception that the system is unjust raises the costs ...

Ideology is the instrument the public uses to assess and evaluate the programmes of the government they elected. It is also used to understand the 'justness' or otherwise of any political regime and can be used to differentiate between political and economic systems such as dictatorship, totalitarianism, monarchy, and liberal / representative democracy. It is within this framework that 'ideology comes into its own as a way of interpreting and reacting to the world [regime] when it is uncertain ... [Hence it serves as bridge for] unifying models of electoral competition and government formation within an overall theory of democratic decision processes' (Budge 1994, p 448). 
Several studies have argued that there is a lack of ideological inclination among political parties in Africa, resulting in their remaining personal enterprises, dominated and identified by popular and even populist names. Because of this lack of ideological commitment African parties frequently resort to ethnic and tribal appeals so party politics is defined by a triangle of evil: personalisation (control by individuals who treat the party as their personal property), clientelism and corruption (Sandbrook 1996, p 76).

This is a challenge to all political parties, irrespective of whether they were formed at independence or are newly created. Parties should define and distinguish their stand in the political process by constructing ideologically appealing and enticing manifestos. ${ }^{5}$ Budge (1994, p 448) stresses the importance of ideology to the development and institutionalisation of political parties when he avers that because ideologies distinguish themselves by opposing each other they play an important role in decisions about party policy positions. He maintains that

... ideologies encourage multi-partyism [especially] under conditions of limited information and uncertainty. This is because the ideology typically identifies some existing or potential group of supporters for its policy prescriptions. Such supporters could consist of electors currently voting for existing parties ... or electors currently not voting at all because existing ideologies offer no 'real' alternatives.

Typically, the major focus of a party ideology is in the areas of provision of welfare (education, social security, health), total spending, revenue and public employment, foreign and defence policy, and economic policy. These aspects of political governance determine whether a party inclines, ideologically and traditionally, to the left or the right. Indeed, parties in Africa, both ruling and opposition, can be differentiated in terms of these major issues. However, although, it can be argued that following the demise of communism, and the subsequent ascendancy of liberal capitalism, coupled with the impact of globalisation, the ideological debate is declining, the fact is that despite these global changes the debate is and will continue for some time to be relevant to political discourse.

5 Though ideological crisis is one of the problems that confront African political parties it is not the immediate problem because it will be several years before parties internalise the vitality of politics and achieve ideological differentiation. Historically, even in Western Europe, it was not until the 'systemic crises of the inter-war period' that 'highly ideological political parties' emerged (Luther and Müller-Rommel 2002, p 2). 
Ideology will continue to inform policy direction and implementation and to influence the provision of welfare and participation in politics. In fact, the apparent resurgence of socialism in many Latin American countries, especially Bolivia and Venezuela, is rekindling the ideological debate. Of course, debate about ideology will change from traditional capitalist $\mathrm{v}$ communist to more contemporary issues of globalisation, international trade, poverty eradication, security and terrorism, millennium development goals, democracy and reforming international organisations,

\section{DOMINANT-PARTY SYSTEMS}

According to Bogaards (2004, pp 174-9) dominant parties are identified and defined by four major criteria: the urge for dominance, the inclusion/exclusion of opposition features, the presence or absence of divided government, and the duration of time. Simply put, party dominance is calculated by the percentage of votes or share of seats in the legislature. However, broadly understood, party dominance takes cognisance of the above-mentioned criteria. In this context, drawing on the studies of Van de Walle \& Butler (1999), Ware (1996), Sartori (1976), Coleman (1960), Blondel (1968) and Pempel (1990b), Bogaards (2004) diagrammatically defined dominant parties using four criteria, as follows:

Table 3

Conceptualisation of Dominant Parties

\begin{tabular}{|c|c|c|c|c|c|c|c|}
\hline Authors & Coleman & $\begin{array}{l}\text { Van de Walle } \\
\text { \& Butler }\end{array}$ & $\begin{array}{c}\text { Ware } \\
\text { (Predominant) }\end{array}$ & $\begin{array}{c}\text { Sartori } \\
([\text { Pre]dominant })\end{array}$ & $\begin{array}{c}\text { Ware } \\
\text { (Dominant) }\end{array}$ & Blondel & Pempel \\
\hline $\begin{array}{l}\text { Threshold } \\
\text { of } \\
\text { Dominance }\end{array}$ & $\begin{array}{l}70 \% \\
\text { (seats) }\end{array}$ & $\begin{array}{l}60 \% \\
\text { (seats) }\end{array}$ & $\begin{array}{c}50 \% \\
\text { (seats) }\end{array}$ & $\begin{array}{l}50 \% \\
\text { (seats) }\end{array}$ & $\begin{array}{l}45-50 \% \\
\text { (seats) }\end{array}$ & $\begin{array}{c}45-50 \% \\
\text { (seats) } \\
\text { Double the } \\
\text { vote share } \\
\text { of the } \\
\text { runner-up }\end{array}$ & $\begin{array}{c}\text { Plurality } \\
\text { (votes \& } \\
\text { seats) }\end{array}$ \\
\hline Opposition & Dispersed & - & Divided & - & $\begin{array}{l}\text { Several } \\
\text { smaller } \\
\text { parties }\end{array}$ & $\begin{array}{c}\text { Multiple } \\
\text { opposition } \\
\text { helpful }\end{array}$ & $\begin{array}{c}\text { Inferior } \\
\text { bargaining } \\
\text { position }\end{array}$ \\
\hline President & - & - & - & $\begin{array}{l}\text { No divided } \\
\text { government } \\
\text { (Bogaards's } \\
\text { addition) }\end{array}$ & - & - & - \\
\hline Duration & $\begin{array}{c}\text { Analysis } \\
\text { limited } \\
\text { to single } \\
\text { election }\end{array}$ & $\begin{array}{l}\text { Analysis } \\
\text { limited } \\
\text { to single } \\
\text { election }\end{array}$ & Permanent & $\begin{array}{c}\text { Three } \\
\text { consecutive } \\
\text { elections }\end{array}$ & $\begin{array}{c}\text { Dominant } \\
\text { party should } \\
\text { 'usually' } \\
\text { win }\end{array}$ & $\begin{array}{c}\text { Analysis } \\
\text { over 20- } \\
\text { year } \\
\text { period }\end{array}$ & $\begin{array}{c}\text { 'Substantial } \\
\text { period' }\end{array}$ \\
\hline
\end{tabular}

Source: Bogaards 2004, p 176 
Table 3 shows that irrespective of which definition of dominant parties one chooses this scenario is evident in African democracies. The dominant parties are ruling parties, which use state resources, political patronage and clientelism to consolidate themselves and eliminate the opposition.

Table 4

Dominant-Party Scenarios in Selected African Democracies

\begin{tabular}{|c|c|c|c|c|c|c|c|}
\hline Country & $\begin{array}{l}\text { Last } \\
\text { Election }\end{array}$ & $\begin{array}{l}\text { Total } \\
\text { Parlia- } \\
\text { ments }\end{array}$ & $\begin{array}{l}\text { Dominant } \\
\text { Party }\end{array}$ & $\begin{array}{l}\text { Dominant. } \\
\text { Party(s) } \\
\text { Seats }\end{array}$ & $\begin{array}{l}\text { Seats } \\
\text { of other } \\
\text { Parties }\end{array}$ & $\begin{array}{l}\text { Dominant } \\
\text { Party(s) } \\
\text { Seats \% }\end{array}$ & $\begin{array}{l}\text { Seats } \\
\text { of other } \\
\text { Parties \% }\end{array}$ \\
\hline Angola & 1992 & 220 & MPLA & 129 & 91 & 58,6 & 41,4 \\
\hline Benin & 2003 & 83 & UBF & 52 & 31 & 62,7 & 37,3 \\
\hline Botswana & 2004 & $57^{6}$ & BDP & 44 & 13 & 77,2 & 22,8 \\
\hline Burkina Faso & 2002 & 111 & CDP & 57 & 54 & 51,4 & 48,6 \\
\hline Burundi & 2005 & $118^{7}$ & CNDD-FDD & 64 & 54 & 54,2 & 45,8 \\
\hline Cameroon & 2002 & 180 & RDPC & 149 & 31 & 82,8 & 17,2 \\
\hline Cape Verde & 2006 & 72 & PAICV & 41 & 31 & 56,9 & 43,1 \\
\hline C. A. Republic & 2005 & 105 & $\mathrm{NC}[\mathrm{KNK}]$ & 42 & 63 & 40,0 & 60,0 \\
\hline Chad & 2002 & 155 & MPS & 110 & 45 & 71,0 & 29,0 \\
\hline Comoros & 2004 & $18^{8}$ & CDIA & 12 & 6 & 66,7 & 33,3 \\
\hline Congo (Braz.) & 2002 & $137^{9}$ & PCT-FDU & 83 & 46 & 60,6 & 33,6 \\
\hline Côte d'Ivoire & 2000 & 225 & FPI & 96 & 129 & 42,7 & 57,3 \\
\hline Djibouti & 2003 & 65 & UMP & 65 & 0 & 100,0 & 0,0 \\
\hline E. Guinea & 2004 & 100 & PDGE-Allies & 98 & 2 & 98,0 & 2,0 \\
\hline Ethiopia & 2005 & 547 & EPRDF & 327 & 220 & 59,8 & 40,2 \\
\hline Gabon & 2001 & 120 & PDG & 86 & 34 & 71,7 & 28,3 \\
\hline The Gambia & 2002 & $48^{10}$ & APRC & 45 & 3 & 93,8 & 6,3 \\
\hline Ghana & 2005 & 230 & NPP & 128 & 102 & 55,7 & 44,3 \\
\hline Guinea & 2002 & 114 & PUP & 85 & 29 & 74,6 & 25,4 \\
\hline Guinea Bissau & 2004 & 100 & PAIGC & 45 & 55 & 45,0 & 55,0 \\
\hline Kenya & 2002 & 224 & NARC $^{11}$ & 132 & 92 & 58,9 & 41,1 \\
\hline Lesotho & 2002 & 120 & LCD & 77 & 43 & 64,2 & 35,8 \\
\hline Liberia & 2005 & 64 & $\mathrm{CDC}^{12}$ & 15 & 49 & 23,4 & 76,6 \\
\hline Madagascar & 2002 & 160 & TIM & 103 & 57 & 64,4 & 35,6 \\
\hline Malawi & 2004 & 193 & MCP & 59 & 134 & 30,6 & 69,4 \\
\hline Mali & 2002 & 147 & $\begin{array}{l}\text { RPM \& } \\
\text { Other Parties }{ }^{13}\end{array}$ & 66 & 81 & 44,9 & 55,1 \\
\hline
\end{tabular}




\begin{tabular}{|l|c|r|l|r|r|r|c|}
\hline Mauritania & 2001 & 81 & PRDS & 64 & 17 & 79,0 & 21,0 \\
\hline Mauritius & 2005 & 70 & AS & 42 & 28 & 60,0 & 40,0 \\
\hline Mozambique $^{14}$ & 2004 & 250 & FRELIMO & 160 & 90 & 64,0 & 36,0 \\
\hline Namibia & 2004 & 72 & SWAPO & 55 & 17 & 76,4 & 23,6 \\
\hline Niger & 2004 & 113 & $\begin{array}{l}\text { MNSD- } \\
\text { Nassara }\end{array}$ & 47 & 66 & 41,6 & 58,4 \\
\hline Nigeria & 2003 & $109^{15}$ & PDP & 76 & 33 & 69,7 & 30,3 \\
\hline Rwanda & 2003 & $53^{16}$ & FPR & 33 & 20 & 62,3 & 37,7 \\
\hline $\begin{array}{l}\text { São Tomé \& } \\
\text { Príncipe }\end{array}$ & 2006 & 55 & MDFM-PCD & 23 & 32 & 41,8 & 58,2 \\
\hline Senegal & 2001 & 120 & SOPI & 89 & 31 & 74,2 & 25,8 \\
\hline Seychelles & 2002 & 34 & SPPF & 23 & 11 & 67,6 & 32,4 \\
\hline Sierra Leone & 2002 & $112^{17}$ & SLPP & 83 & 29 & 74,1 & 25,9 \\
\hline South Africa & 2004 & 400 & ANC & 279 & 121 & 69,8 & 30,3 \\
\hline Tanzania & 2005 & $323^{18}$ & CCM & 275 & 48 & 85,1 & 14,9 \\
\hline Togo & 2002 & 81 & RPT & 72 & 9 & 88,9 & 11,1 \\
\hline Uganda & 2006 & 284 & NRM & 191 & 93 & 67,3 & 32,7 \\
\hline Zambia & 2001 & $150^{19}$ & MMD & 69 & 81 & 46,0 & 54,0 \\
\hline Zimbabwe 20 & 2005 & 50 & ZANU-PF & 43 & 7 & 86,0 & 14,0 \\
\hline
\end{tabular}

Source: Compiled and Calculated from 'African Election Data: A Database for Election Results in SubSaharan Africa', <http:/ / africanelections.tripod.com/index.html>, July 2006.

6 Four members are indirectly elected and the president and attorney general are ex-officio members of the National Assembly.

7100 seats are directly elected by the voters; 18 are allocated based on the constitutional requirements that the CNDD-FDD coalition has 64 seats; other parties shared 54, including 3 reserved for the Twa ethnic group.

815 members are indirectly elected by the Assemblies of the three islands in the state.

9 Elections for 8 seats were postponed because of militia operation in the area of Pool Region, hence they are not included in the statistics.

10 Five additional members are directly appointed by the president.

11 Coalition of four parties: Liberal Democratic Party, Democratic Party, Forum FORD-K and National Party of Kenya.

12 CDC has the majority in the Parliament, but the presidential election was won by the UP.

13 Malians in the Diaspora are represented by 13 parliamentary seats, elected in a separate election.

1419 parties participated in the election; the seats were won by the two parties only.

15 Only the Senate result was used. Nigeria operates a bicameral legislature. In both chambers of the National Assembly the PDP is in control with a two-thirds majority. The party also controls 27 of the 36 states, and 28 State Houses of Assemblies. This by no means makes the democracy a dominantparty system. However, in the 2007 elections, which were domestically and internally condemned as sham, the PDP still maintained its dominance. Most of the election results are being contested, including the presidential election.

16 Additional 27 members indirectly elected, not included here.

17 Additional 12 seats reserved for paramount chiefs, not included in the figures.

18 Additional 10 seats appointed by the president.

$19150 \mathrm{MPs}$ directly elected by the people. Additional 8 members appointed by the president not included here.

20 Zimbabwe has a bicameral legislature but only the upper chamber result was used as it reflects what obtains in the lower chamber. 


\begin{tabular}{|c|c|}
\hline APRC & Alliance for Patriotic Reorientation and Construction \\
\hline AS & Social Alliance \\
\hline CDC & Congress for Democratic Change \\
\hline CDIA & Camp of the Autonomous Island \\
\hline CDP & Congress for Democracy and Progress \\
\hline CNDD-FDD & $\begin{array}{l}\text { National Council for the Defence of Democracy-Forces for } \\
\text { the Defence of Democracy }\end{array}$ \\
\hline $\mathrm{DP}$ & Democratic Party \\
\hline EPRDF & Ethiopia People's Revolutionary Democratic Front \\
\hline FPI & Ivorian Popular Front \\
\hline FPR & Rwanda Patriotic Front \\
\hline LDC & Lesotho Congress for Democracy \\
\hline LDP & Liberal Democratic Party \\
\hline MDFM-PCD & Force for Change Democratic Movement-Democratic Convergence Party \\
\hline MMD & Movement for Multiparty Democracy \\
\hline MPS & Patriotic Salvation Movement \\
\hline NARC & National Rainbow Coalition \\
\hline $\mathrm{NC}[\mathrm{KNK}]$ & National Convergence 'Kwa Na Kwa' \\
\hline NPP & Northern People's Party \\
\hline NRM & National Resistance Movement \\
\hline PAICV & African Party for the Independence of Cape Verde \\
\hline PAIGC & African Party for the Independence of Guinea and Cape Verde \\
\hline PCT-FDU & Congolese Labour Party-United Democratic Forces \\
\hline PDG & Gabonese Democratic Party \\
\hline PDGE & Democratic Party of Equatorial Guinea \\
\hline PDP & People's Democratic Party \\
\hline RTP & Rally for the Togolese People \\
\hline PRDS & Democratic and Social Republican party \\
\hline PUP & Party of Unity and Progress \\
\hline RDPC & Cameroon People's Democratic Party \\
\hline RPM & Rally for Malawi \\
\hline SLPP & Sierra Leone People's Party \\
\hline SPPF & Seychelles People's Progressive Front \\
\hline TIM & I Love Madagascar \\
\hline UBF & Union for the Benin of the Future \\
\hline UMP & Union for Presidential Majority \\
\hline UP & Unity Party \\
\hline
\end{tabular}


Table 4 further clarifies the dominant-party picture of African democracy and the almost total elimination of opposition parties. In fact, even in states such as Liberia and Ghana where the opposition has a reasonable number of seats in Parliament the situation may not be sustainable. In Ghana the opposition party won the election in 2005, but the former ruling party, based on its popular support, was able to win 44 per cent of the seats. In Liberia, the UP was only able to win the presidential election in the second round. Gorge Weah's CDC won the largest percentage of the seats in the parliamentary election and looked poised to win the presidential election. If it had not been for the fact that Weah's political personality was no match for Ellen Johnson-Sirleaf's experience and international popularity, the CDC would also have formed the government, giving us yet another dominant-party scenario.

As the statistics reveal, from Zimbabwe to Rwanda, Nigeria to Madagascar, through Equatorial Guinea to Botswana, with the exception of Malawi, the situation is the same and dominant parties have 'systematically outlawed every attempt by the opposition parties to gain equitable and proportional access to political power', often doing so by introducing various electoral laws and changing constitutions on the eve of elections (Olaleye 2003, p 5).

Perhaps the lack of ideological inclination among political parties in Africa and their personalistic, and clientelistic characteristics have not only made them vulnerable to selfish tendencies but have led to the development of 'dominantparty systems'. Despite the proliferation of parties following the 'opening up' of the 1990s, the political scene is dominated by only a few parties. The transformation of the African political landscape has seen the one-party system give way to the dominant- party system in that, in some countries, such as Mali, São Tome and Principe, Equatorial Guinea, Burundi, Congo-Brazzaville, and so on, the ruling parties collaborate with smaller parties to win dominance in the legislature.

The tendency in this kind of electoral coalition is that the smaller parties are either extensions of the ruling parties or the ruling parties have infiltrated their leadership in order to render them ineffectual and susceptible to the ruling parties' political manipulation and co-options. The most dangerous scenario signalled by the appearance of dominant-party system is that the pattern and nature of governance have not change. The so-called democratically elected leaders have continued to rule with extraordinary iron hands and have simply become dictators in disguise. For instance, in a study of about 18 African countries, Bogaards (2004, p 192) argues that 'one party [or at most two parties] has an absolute majority of seats in legislature and can govern alone'.

It is therefore not ironic to posit that dominant parties may, in the long run, degenerate into authoritarianism and have a deleterious effect on the development 
of liberal democracy (Giliomee \& Simkins 1999 and Van de Walle \& Butler 1999). The dominant-party system also points to the general problem with former military and civilian dictators who want to maintain the status quo. In order to achieve this, they employ all manner of illegal and extra-legal measures, from cooption and clientelism to patronage and the muscling out of the opposition.

The nature of the socio-political environment contributes to this scenario. The opposition parties are always divided and, at times, remain acquiescent in the maintenance of the status quo. For example, in Nigeria, the PDP is the strongest and largest party and, since the return of democracy to the country, not only have the opposition parties remained divided, they are also dominated by intraparty conflicts to which the PDP has been accused of being party. Perhaps in order to provide a viable opposition to the ruling party, all 29 opposition parties came together under the banner of the Conference of Nigerian Political Parties (CNPP). However, this did not threaten the formidable PDP or change the system of democratic governance in the country. This failure is attributable to internal wrangling within the individual opposition parties. The lack of visibility of the opposition thwarts the democratic process (Kura 2005, p 24). This further suggests that despite the transformation undergone by the parties after the return of multiparty elections, the competitive multiparty system presents a challenge to political parties in Africa.

One of the essential components of multiparty democracy is the presence of an opposition to act as a check on abuse of power by the ruling party, which supplements the checks and balances of the legislature. However, it is clear from Table 4 that there is no such strong opposition in Africa. Political parties out of government have failed, therefore, to provide the required opposition for the development of healthy, sustainable democracy. In addition, most opposition parties face serious internal problems, lack legitimacy, and are so fragmented that they cannot even unite as a coalition to make themselves a force in the political process. This situation spells doom for the opposition as well as for the development of sustainable democracy in Africa.

\section{PARTY FUNDING AND FINANCE}

In general terms the economic underdevelopment of African states has made political party institutions more vulnerable to grossly inadequate resources and finance for the conduct of their activities. To say that democracy is a capitalintensive project is an understatement. The major sources of party funding include membership dues, individual and corporate donations, state grants, and international assistance. Given the degenerating nature of party membership and the economic hardship of the people (even if members pay their dues) this 
represents an insignificant amount in the financial account of the parties. ${ }^{21}$ The problem with individual and corporate funding is that donations come with strict conditions and are seldom regulated in the same way as public finances. There is a risk of money influencing the political process and parties may not be accountable, let alone discharge their democratic functions (Patel 2005, p 10).

Beyond these problems individual and corporate funding of political parties may jeopardise public policy-making. Parties are usually forced to adhere strictly to the terms and conditions of agreements entered into with 'sponsors'. Parties thus become more accountable, not to the public but to the individuals or groups who finance their activities. However, today there is considerable pressure for state funding of political parties, which could reduce the problem of individuals or groups hijacking parties to advance narrow interests. In the same way, foreign funding of democratisation could be extended to political parties. ${ }^{22}$

\section{INEFFECTUAL CIVIL SOCIETY OPPOSITION}

The problem of dominant-party systems has snowballed into the general and more delicate problem of ineffectual political opposition. While political parties are affected by socio-cultural and economic problems, the larger civil societies in Africa are not doing any better either. The term civil society is comprehensive and broadly encompasses all socio-cultural and political activities outside the government. This comprehensiveness is partly responsible for the loose way the term is used to denote even issues that are outside the boundaries of civil society. Carothers \& Barndt (2000, p 19), appreciating this ambiguity, argue that 'properly understood, civil society is a broader concept, encompassing all the organisations and associations that exist outside of the state (including political parties) and the market'. Examples of civil society organisations are: labour unions, professional associations, ethical and religious associations, students' associations, and so on.

Civil society organisations (CSOs) play a fundamental role in the development of sustainable democracy. They shape governance and policy issues by pressuring government and providing 'expertise' to government and policymakers. However, for CSOs to be robust and provide the necessary impetus to the democratic process, they must be resourceful, dedicated and diligent.

21 For example, Nigeria's PDP charged each member N10 for revalidation of his/her membership. The amount is insignificant, which means every member of the party can pay. The value of the payment lies in the members' commitment to the philosophy and ideals of the party specifically and multiparty democracy in general.

22 On this debate, see, for example, Burnell (2000). Several international organisations and advanced democracies are engaged in providing assistance in the development of democracies and particularly the development of political parties in Third World states. 
During the re-democratisation process of the 1990s civil society was at the forefront of the fight against military and political dictatorships. For example, Gyimah-Boadi (1996) observes that in Benin, Zambia, Mali, Niger, Ghana, Kenya, Togo, Malawi, and several other third- and fourth-wave democracies, civil society was rigorous in fighting one-party dictatorships and military authoritarianism. But despite this singular achievement, while African states are democratically undergoing transformation, civil society organisations have become 'too weak to redress state-society relations in favour of the latter ..., failed to transcend ethnoregional, religious and other cleavages in any lasting way' through ideological and principled opposition and mobilisation. Thus, civil society has, either through commission and/or omission, become invisible in the political process. In many states it either waned, was co-opted, or had serious crises over resources and leadership and thereby lost its political relevance.

Where it is visible it tends to be weak and thus unable to invigorate the political process. This is perhaps why some political analysts are very sceptical about the role of civil society in bridging the gap between the governors and the governed, especially in fledging African democracies. In Africa the 'existence of a wide range of civil society organisations gives no guarantee that any will articulate norms which further the development of a tolerant or participatory public arena' (Bartlett 2000, p 445).

Like most of the parties, civil society organisations have become conduits for achieving political relevance and tapping national resources. In a broader sense African civil societies are relatively weak and are besieged by financial, organisational, operational and domestic constraints (Makumbe 1998, p 316). This might be the justification for the inability of civil society to provide a political voice in the democratic governance process in Africa.

Conventionally, civil society organisations, especially in the absence of a credible opposition, should check the excesses of the ruling party, preventing it from descending into authoritarianism. The challenge for African political systems is to provide civic education that will lead to the growth and development of opposition parties, or, better still, a populace that is responsive and responsible. International donors should continue to come to the rescue by providing adequate financial and moral support for the development of vibrant opposition parties and civil society organisations that will invigorate the democratic process for better governance and the development of sustainable democracy.

\section{DEFECTIVE ELECTORAL SYSTEMS}

As political parties are central to democracy, so elections are important to the development of a stable, competitive party system. Conducting free and fair 
elections is one thing, acceptance of the elections as free and fair is another and remains one of the most difficult aspects of party politics in Africa. However, organising free and fair elections is a constitutional responsibility of electoral institutions, consequently electoral institutions are an important ingredient of representative democracy. Patel (2005) observes that the nature of the democratic institutions established by a state is integral to and determines the degree of success of the new regime because these institutions define the political process. The electoral institution is therefore important for five reasons.

- It contributes to the evolution of a political party culture that defines the differences between parties.

- It determines the pattern of legislative representation.

- It determines the occupant(s) of government (Patel 2005).

- It sets the parameters for stable political competition.

- It gives the ruling party (government) political legitimacy.

For any electoral institution to achieve these aims it must be equipped with both human and financial resources. However, the choice of the type of electoral system is determined to a very significant degree by the history of the country, the political and administrative system, and the capacity of the state's economy.

It is unfortunate that while African political parties are undergoing transformation states haphazardly adopt a particular electoral system without due scrutiny and debate. This has thrown many states into electoral dilemmas and political crisis. For example, the adoption of a first-past-the post (FPTP) system has often made it easier for only the winning party to have an absolute majority and thus to rule without strong opposition. Seats won by opposition parties are not proportionate to the vote for those parties and the opposition is often silenced through cooption and patronage.

Whichever electoral system is adopted and irrespective of problems that might affect the pattern of electioneering, political parties tend to aggravate the problem by dismissing all election results as fraudulent. It is rare for defeated parties in Africa to accept defeat without question, a situation which affects the legitimacy of government and sometimes makes countries hard to govern.

If parties and elections are two sides of the same coin electoral institutions must organise free and fair elections and parties must learn to accept the results. An election is the only legal means by which 'a large proportion of the citizenry participate in selecting and removing political representatives, it provides a primary source of democratic legitimacy' (Lindberg 2004a, p 3). Effective electoral systems and institutionalised political parties give flavour to sound democratic governance. 
In contemporary African democracies many electoral institutions are constitutionally under the direct control of the president, thus giving them official licence to rig elections in favour of the ruling party. For example, the 1999 Constitution which ushered in the current democratic regime in Nigeria gives unprecedented power to the president to appoint the chairman of the Independent National Electoral Commission (INEC), his major lieutenants and the resident electoral commissioners (RECs) of the 36 states and Abuja. No wonder, therefore, that opposition parties allege that all the officers of the INEC are card-carrying members of the president's party, the PDP (Mada 2006).

The Constitution gives similar powers to state executive governors. In fact, the 1999 Constitution plays a fundamental role in bringing INEC officials under the direct control of the ruling party, thereby giving it the opportunity not only to rig elections but to destroy opposition candidates. It is significant that even INEC's budgets are directly controlled by the president. Even if the legislature intervenes, as it does on occasion, INEC finances are released piecemeal, rendering the commission relatively ineffective to organise and conduct free and fair elections. That is why perhaps, these institutional anomalies contributed to the PDP massively rigging the 2003 elections, which the opposition All Nigeria People's Party (ANPP), contested unsuccessfully in court. However, the conduct of the 2007 election demonstrated that Nigeria has not learnt from history. None of the institutional anomalies responsible for the near failure of the 2003 election has been addressed. Thus both local and foreign observers judged the 2007 election as the worst in Nigeria's political history. The outcome of the election left elected officials struggling to assert their legitimacy. The implications are disastrous to party institutionalisation as well as to the development of democracy in the country (for the nature of the 2007 election, see ICG 2007). The Nigerian case is typical of the situation of many electoral bodies in African contemporary democracies.

\section{THE FUTURE: TOWARDS SUSTAINABLE DEMOCRACY}

Sustainability of democracy in Africa, as elsewhere, is premised on the institutionalisation of political parties and institutionalisation of the parties depends now and in the future on their ability to stay focused on their mission and vision and to transform themselves in accordance with the socioeconomic and political conditions under which they operate (Wanjohi 2003, p 239). It also depends on the clear vision of leaders and on the way members are incorporated into the daily business of party politicking.

Parties must define clearly what they want to achieve and how they are going to achieve it within the limits of their resources. There must be a systematic 
analysis of the environment within which they operate and a clear review process for flexibility. Parties must be dynamic and resourceful and their mission and vision must be built on clear-cut values derived largely from the attitudes, feelings, beliefs and judgement of their members and leaders, factors which aid in the articulate construction of the party's ideology and philosophy.

Given the dominant-party system situation in African democracies there should be a systematically coordinated coalition of political parties, not only in order to wrest power from the incumbent but, importantly, to provide policybased opposition, devoid of the primordial, parochial and personalised political battles that frequently divide the loyalty of party members. In addition, institutionalisation of the parties depends to a very great extent on their organisational complexities, adaptation, dynamism and flexibility, their resource base, rationality in embracing organisational change, and appreciation of the circumstances under which they were formed and established.

Though the contemporary international system is favourable in terms of assuring a bright future for democratic sustainability through political support and aid from developed democracies, international financial institutions and other donor agencies, much responsibility rests on political parties and other democratic stakeholders vis-à-vis the development of sustainable democracy. Given the pivotal role of parties in democratic governance, this paper articulates the essentiality of good governance as a political mechanism for addressing the imbalance between political parties and sustainable democracy.

There has been a recent upsurge of interest among policy makers, analysts, and academics in good governance as an essential ingredient in addressing major development problems. The term good governance made its first appearance in 1989, when the World Bank identified the lack of it as the main reason for Africa's development problem. Despite, this there is 'no obvious literature available on political parties and their governance-related activities' (Hout 2003, p 259). Though there is a great deal of literature linking political parties to democracy generally, little, if any, has been developed on the issue of good governance, political parties and the sustainability of democracy, particularly in Africa. Conceptually, governance is the way institutions and individuals manage their activities (CGD 1995); it is the overall management of a nation's affairs (World Bank 1989). UNDP (1997) observes that governance is the

exercise of economic, political and administrative authority to manage a country's affairs at all levels. It comprises the mechanism, processes and institutions through which citizens and groups articulate their interests, exercise legal rights, meet their obligations and mediate their differences. 
Governance is, therefore, the process of decision-making, implementation, and even outcome. What happens in this chain is where good and/or bad governance comes in. So, good governance determines the desired outcome of the policies implemented by formal and informal institutions, either public or private. Good governance, logically, involves the proper application of the relevant tenets of governance in the management and administration of the affairs of a state. In this context, while democracy is a means to development, good governance is a means to ensuring the growth of sustainable democracy, and political parties are the pivotal institutions that could mediate between the two.

Drawing on Leftwich (1994) and Hoebink (2001) Hout (2003) identifies two definitions of good governance: technocratic good governance, which emphasises accountability, legality, availability of information, and transparency; and the political meaning that concentrates on the nature and organisation of political and legal institutions in developing countries. Though it seems easy good governance can only be defined by identifying its key features. The differences of opinion thus limit our search for appropriate definitions. The main characteristics of good governance are detailed in the box below.

Based on the above conceptual typologies and the core characteristics of good governance, a strong link can be established between political parties, good governance and sustainable democracy. Accordingly, while technocratic interpretations of good governance do not directly 'recognise political parties as actors that are necessarily central to the way a country is governed', the political interpretation explicitly identifies 'the existence of a set of active political parties [as] a conditio sine qua non for the achievement of good governance...' (Hout 2003, p 261).

Beyond this, the governance role of political parties has also directly and indirectly exposed how indispensable they are to the employment of good governance as a panacea for the major problems associated with institutionalisation and how they can influence critically other private and public institutions for the development of sustainable democracy.

It can be conveniently hypothesised that there is a strong correlation between good governance on the one hand and party institutionalisation and democratic sustainability in Africa on the other. In other words, through their procedural and substantive role not only in the establishment of democracy itself but also in making it workable, political parties are the custodians of modern representative democracy.

The importance of good governance is that it is the only solution that addresses not only the problems of political parties but other institutional and structural problems that threaten the development of sustainable democracy in Africa. 


\section{The Main Characteristics of Good Governance}

- Participation: citizens have a say in the decision-making process through legitimate institutions, interest groups, individuals, and political parties. This input is based on a guarantee of liberty and freedom of association and speech, free media, and the capacity to participate constructively.

- Rule of Law: the framework of adjudication should be fair and work objectively and without prejudice.

- Transparency: there should be a free flow of information for public consumption, and citizens should have unreserved access to decision-making processes, institutions, and adequate information to monitor the processes of policymaking, implementation and outcomes.

- Responsiveness: public and private institutions and processes should act within a reasonable time to serve all relevant stakeholders.

- Equity: all citizens have an equal opportunity to improve and maintain their lives without discrimination.

- Effectiveness \& Efficiency: institutions and decision-making and implementation processes must produce results that meet society's needs. This also pertains to the sustainable use of resources and protection of the environment.

- Accountability: all informal and formal institutional stakeholders should be accountable to the general public though the extent of the accountability might differ from institution to institution, depending on the nature of their operations and the outcome of their services.

- Strategic Vision: the leadership and the civil society have a long terms and sustainable vision of good governance and democracy and development. This should also take into consideration the historical, socio-cultural and political complexities of the state.

- Free \& Fair Elections: elections are the single must important indicator of direct public political participation and provide legitimacy to regimes. Periodic elections must not only be free and fair, they must be seen to be to be free, fair and honestly contested.

- Consensus orientation: conflict is a norm in political and economic interactions. Thus there should be broad consensus on important political, social and economic policy issues that affect society as a whole. 


\section{CONCLUSION}

The return of democracy during the 'third' and 'fourth' waves has raised new hopes and aspirations for all African citizens. However, the road towards democratic sustainability involves the activities of several institutional stakeholders, with political parties at the heart of the process. African political parties are undergoing critical changes and facing daunting challenges.

These results of the changes have been palpable, with many countries conducting more than three consecutive elections. In some states, Ghana for example, not only were there successful elections, there was also a peaceful transfer of power from one party to another. These changes have not, in themselves, contributed to deepening democratisation on the continent. Nearly two-thirds of African states are 'partly free' or 'not free at all'. Despite this, though, there have been fundamental changes, especially compared to the situation in the 1970s and 1980s. The changes have further raised the hopes not only of Africans but of the international community that democracy has come to stay in Africa. But, though there have been many changes, the problems of parties with undefined political ideologies, a docile civil society, questions of party funding, and the dominantparty system still seem to threaten the institutionalisation of parties for the development of sustainable democracy.

Despite these challenges, and against the background of the contemporary international system and the keen interest being shown by international organisations and donor countries in the plight of Africa, African political parties have a future. However, this future lies in the domestic structuring of governance. No matter the extent of the concern about Africa and the amount of resources disbursed to the continent, if there is no sound evidence of good democratic governance the same stories will continue to be written about it.

\section{- REFERENCES}

Aldrich, J H. 1995. Why Parties? The Origin and Transformation of Political Parties in America. Chicago: University of Chicago Press.

—_ 1997. 'Political Parties in a Critical Era'. Paper for the Bliss Institute Conference, The State of the Parties: 1996 and Beyond, University of Akon, 9-10 October.

Akinyele, T M. 2004. 'The 2003 Elections that Broke the Jinx'. West Africa Review 5. Amundsen, I. 2001. 'The Limits of Clientism: Multi-Party Politics in Sub-Saharan Africa'. Forum for Development Studies, 1 June.

Bartlett, M C D. 2000. 'Civil Society and Democracy: A Zambian Case Study'. Journal of Southern African Studies 26(3). 
Blondel, J. 1968. 'Party Systems and Patterns of Government in Western Democracies'. Canadian Journal of Political Science 1(2).

Bogaards, M. 2004. 'Counting Parties and Identifying Dominant Party System in Africa'. European Journal of Political Research 43(2).

Budge, I. 1994. 'New Spatial Theory of Party Competition: Uncertainty, Ideology and Policy Equilibrium Viewed Comparatively and Temporally'. British Journal of Political Science 24(4), October.

Burnell, P. 2000, 'Promoting Parties and Party Systems in New Democracies: Is There Anything the International Community Can Do?' Paper for the Political Studies Association PSA, UK, 50 th Annual Conference, London, 10-13 April.

— \& V Randall. 2004. 'Case Study One: Political Parties, Their Social Ties and Role in Political Change'. In P Burnell \& V Randall (eds). Politics in the Developing World. Oxford: Oxford University Press.

Carothers, T \& W Barndt. 2000. 'Civil Society'. Foreign Policy 117, Winter.

Carey, S. 2001. 'A Comparative Analysis of Political Parties in Kenya, Zambia and Former Zaire'. Paper for the 29th ECPR Joint Session, Workshop 13: Parties, Party Systems and Democratic Consolidation in the Third World, 6-11 April, Grenoble, France.

Catto, M. 2000 ‘Defining Party and Government'. In J Blondel \& M Cotta (eds). The Nature of Party Government: A Comparative European Perspective. New York: Palgrave.

Centre for Development and Governance (CDG). 2005. 'New Law: Political Parties to be Funded by the State'. CDG Policy Brief. Nairobi: CDG Forum on Party Management and Financing.

Chiroro, B. 2005. 'Political Parties and Democratic Governance: South Africa and Zimbabwe'. Paper presented at the UNISA Africa Conference, UNISA, Pretoria, 2 June.

Coleman, J S. 1960. 'The Political Systems of the Developing Areas'. In G A Almond and J S Coleman (eds). The Politics of the Developing Areas. Princeton, NJ: Princeton University Press.

Commission on Global Governance. 1995. Our Global Neighborhood: The Report of the Commission on Global Governance. Oxford: Oxford University Press.

Cox, G W \& M McCubbins.1993. Legislative Leviathan: Party Government in the House. Berkeley, CA: University of California Press.

David, R. 1976. A Theory of Party Competition. London: John Wiley.

Diamond, L. 1997. 'Introduction: in Search of Consolidation'. In L Diamond, M F Plattner, Y Chu and H Tien (eds). Consolidating the Third Wave Democracies: Themes and Perspectives. Baltimore, MD: Johns Hopkins University Press.

_ \& R Gunther. 2003. 'Species of Political Parties'. Party Politics 9(2). 
—. 2001, 'Types and Functions of Parties'. In L Diamond \& R Gunther (eds). Political Parties and Democracy. Baltimore: The Johns Hopkins University Press.

Dutt, P \& D Mitra. 2005 'Political Ideology and Endogenous Trade Policy: An Empirical Investigation'. The Review of Economics and Statistics 87, February. Duverger, M. 1954. Political Parties: Their Organisation and Activity in the Modern State. London: Metheun.

Emerson, R. 1966. 'Political Parties and National Integration in Africa'. In J LaPalombara \& M Weiner (eds). Political Parties and Political Development. Princeton: Princeton University Press.

Epstein, L D. 1967. Political Parties in Western Democracies. New York: Praeger.

Freedom House. 2006. Freedom in the World 2006: Selected Data from Freedom House's Annual Global Survey of Political Rights and Civil Liberties. Available online at $<$ www.freedomhouse.org / template.cfm?page=35\&year=2006>

Gentili, A M. 2005. 'Party, Party Systems and Democratisation in Sub-Saharan Africa'. Paper presented at the Sixth Global Forum on Reinventing Government, Seoul, Republic of Korea, 24-27 May.

Giliomee, H \& C Simkins (eds). 1999. The Awkward Embrace: One-Party Domination and Democracy. Amsterdam: Harwood.

Gyimah-Boadi, E. 1996. 'Civil Society in Africa'. Journal of Democracy 7(2).

Henig, S \& J Pinder (eds). 1969. European Political Parties. London: George Allen \& Unwin Ltd.

Hodgkin, T. 1961. African Political Parties: An Introductory Guide. London: Penguin. Hoebink, P. 2001. ‘Good Governance Als Voowaarde en Doel bij Enkele Europese Donoren [Good Governance as Condition and Objective for some European Donors]'. Scientific Council for Government Policy Report 56.

Hout, W. 2003. 'Political and Governance'. In M A Mohamed Salih (ed). African Political Parties: Evolution, Institutionalisation and Governance. London: Pluto Press.

Huntington, S P. 1968. Political Order in Changing Societies. New Haven and London: Yale University Press.

—. 1991. The Third Wave: Democratization in the Late Twentieth Century. Norman: University of Oklahoma Press.

—. 1996. 'Democracy Long Haul'. Journal of Democracy. 7(2).

Ignazi, P. 1996. 'The Crisis of Parties and the Rise of New Political Parties'. Party Politics 2(4).

International Crisis Group. 2007. 'Nigeria: Failed Elections, Failing State?'. Africa Report 126, May.

Janda, K. 1980. Political Parties: A Cross-National Survey. New York: The Free Press. . 1993. 'Comparative Political Science: Research and Theory'. In A W Finifter 
(ed). Political Science: The State of the Discipline, vol 2. Washington, DC: America Political Science Association. An online version <janda.org/ comparative\%20parties/janda_on_parties.htm>.

Katz, R S. 1986. 'Party Government: A Rationalistic Conception'. In G C Francis $\&$ W Rudolf (eds). Vision and Realities of Party Government. Berlin: Walter de Gruyter.

1992. 'Introduction: The Cross-National Study of Party Organisations'. In R S Katz \& P Mair (eds). Party Organisations: A Data Handbook on Party Organisations in Western Democracies, 1960-90. London: Sage Publications. \& P Mair. 1995. 'Changing Models of Party Organization and Party Democracy'. Party Politics 1.

Kau J B \& P H Rubin. 1979. 'Self-interest: Ideology, and Logrolling in Congressional Voting'. Journal of Law and Economics 22 (2).

Kirchheimer, O. 1966. 'The Transformation of the Western European Party Systems'. In J LaPalombara \& M Weiner (eds). Political Parties and Political Development. Princeton, NJ: Princeton University Press.

Kitschelt, H. 1989. The Logics of Party Formation. Ithaca, NY: Cornell University Press.

- 1994. The Transformation of European Social Democracy. Cambridge and New York: Cambridge University Press.

— 2001 'Divergent Paths of Postcommunist Democracies'. In L Diamond \& R Gunther (eds). Political Parties and Democracy. Baltimore: Johns Hopkins University Press.

Kura, S Y B. 2005. 'Towards a Sustainable Democratisation in Nigeria: Defining the Role of and Challenges to Political Parties'. Paper presented at AfricaEurope Group for Interdisciplinary Studies (AEGIS) European Conference on African Studies, London 29 June-2 July.

Lawson, K.1976. The Comparative Study of Political Parties. New York: St. Martin's Press.

Leftwich, A. 1994.'Governance, the State and the Politics of Development'. Development and Change 25(2).

Lindberg, S I. 2004a. 'Consequences of Electoral Systems in Africa: A Preliminary Inquiry'. Electoral Studies available at $<w w w . e l s e v i e r . c o m / l o c a t e /$ elecstud $>$.

—. 2004b. 'When DO Opposition Parties Boycott Elections?'. Paper for the international conference on Democratisation by Elections? The Dynamics of Electoral Authoritarianism, CIDE, Mexico, 2-3 April.

- 2006. 'Opposition Parties and Democratisation in Sub-Saharan Africa'. Journal of Contemporary African Studies. 24(1).

Linz, J J \& A Stepan. 1996. Problems of Democratic Transition and Consolidation: Southern Europe, South America, and Post-Communist Europe. Baltimore and 
London: Johns Hopkins University Press.

Luther, K R \& F Müller-Rommel. 2002. 'Political Parties in a Changing Europe'. Keele European Parties Research Unit (KEPRU), Working Paper 14. School of Politics, International Relations and Environment, Keele University, UK. Mada, B A. 2006. Research Interview Zamfara State SINEC, Nigeria.

Mainwaring, S \& T R Scully. 1995. Building Democratic Institutions: Party System in Latin America. Stanford: Stanford University Press.

Mainwaring, S. 2001. 'Political Parties and Challenges to Democracy'. Reference

Document for Panel I, First Annual Reunion of the Inter-American Forum on Political Parties IAFPP, Miami, December.

Mair, P. 2006. 'Political Parties: What Sort of Future?' Central European Political

Science Review. Also at <www.ics.ul.pt/ceapp/conferencias/fulbright/ 18PMair.pdf>.

Makumbe, J M. 1998. 'Is there a Civil Society in Africa?' International Affairs 74(2).

Marquette, H \& D Mineshima. 2002. 'Civic Education in the United States:

Lessons for the UK'. Parliamentary Affairs 59.

Mboya, T. 1957. Freedom and After. London: Penguin.

Mohamed Salih, M A. 2003. 'Introduction: The Evolution of African Political

Parties'. In MA Mohamed Salih (ed). African Political Parties: Evolution,

Institutionalisation and Governance. London: Pluto Press.

Montero, J R \& R Gunther. 2002. 'Introduction: Reviewing and Assessing Parties'.

In R Gunther, J Ramón-Montero \& J J Linz (eds). Political Parties: Old Concepts and New Challenges. Oxford: Oxford University Press.

Morgenthau, R S. 1964. Political Parties in French-Speaking West Africa. London: Clarendon.

Mozaffar, S \& J R Scarritt. 2005 'The Puzzle of African Party Systems'. Party Politics 11(4).

— , J R Scarritt \& G Galaich. 2003. 'Electoral Institutions, Ethno-political Cleavages, and Party Systems in Africa's Emerging Democracies'. American Political Science Review 97.

Neumann, S. 1956. 'Towards a Comparative Study of Political Parties'. In S Neumann (ed). Modern Political Parties. Chicago, IL: University of Chicago Press.

North,D C.1990. Institutions, Institutional Change, and Economic Performance. Cambridge: Cambridge University Press.

Nyong'o, P A. 1987. Popular Struggles for Democracy in Africa. London: Zed Press.

- 1997 'Institutionalisation of Democratic Governance in Sub-Saharan Africa'. ECDPM Working Paper No 36. Maastricht: ECDPM.

Olaleye, W. 2003. 'Political Parties and Multi-Party Elections in Southern Africa'. SADC Insight IV. 
Panebianco, A. 1988. Political Parties: Organization and Power. Cambridge and New York: Cambridge University Press.

Patel, N. 2005. ‘Political Parties as an Institutional Building Block of Democracy in Africa: Consolidation or Fragmentation?' Paper presented at the Regional Conference on Political Parties and Democratisation in East Africa, Impala Hotel, Arusha, Tanzania, 25-27 August.

Pempel, T J. 1990a. 'Introduction'. In T J Pempel (ed). Uncommon Democracies: The One Party Dominant Regimes. Ithaca, NY/London: Cornell University Press.

— 1990b. 'Conclusion'. In T J. Pempel (ed). Uncommon Democracies: The One Party Dominant Regimes. Ithaca, NY/London: Cornell University Press.

Pickles, D. 1970. Democracy. London: B T Batsford.

Puhle, H. 2002. 'Still the Age of Catch-allism? Volksparteien and Parteienstaat in Crisis and Reequilibration'. In R Gunther, J Ramón Montero \& J J Linz (eds). Political Parties: Old Concepts and New Challenges. Oxford: Oxford University Press.

Randall, V. 1988. 'Conclusion'. In V Randall (ed). Political Parties in the Third World. London: Sage Publications.

.1988a. 'Introduction'. In V Randall (ed). Political Parties in the Third World. London: Sage Publications.

_ \& I Svåsand. 2001. 'Political Parties and Democratic Consolidation in the Third World'. Paper for ECPR Workshop on Parties, Party Systems and Democratic Consolidation in the Third World, 6-11 April, Grenoble, France.

Reiter, H. L. 2006. 'The Study of Political Parties, 1906-2005: The View of the Journals'. American Political Science Review 100(4).

Richard, S. 2004 Nigerian Political Parties: Power in an Emergent African Nation, Fifth Edition, London: Africa World Press.

Robertson, D. 1976 A Theory of Party Competition. London: John Wiley.

Sandbrook, R. 1996. 'Transitions without Consolidation: Democratisation in Six African Cases'. Third World Quarterly 17(1).

Sartori, G. 1976. Parties and Party Systems: A Framework for Analysis, vol. I. London: Cambridge University Press.

Schattschneider, E. E. 1942. Party Government. New York: Holt Rinehart \& Winston. Schmitter, P C. 2001. 'Parties are Not What They Once Were'. In L Diamond \& R Gunther (eds). Political Parties and Democracy. Baltimore: Johns Hopkins University Press.

Sklar, R L. 1967. 'Political Science and National Integration - A Radical Approach'. The Journal of Modern African Studies 5(1).

Smith, B C. 1996. Understanding Third World Politics: Theories of Political Change and Development. London: Macmillan Press Ltd. 
Sørensen, G. 1998. Democracy and Democratisation: Process and Prospects in a Changing World. Boulder \& Oxford: Westview Press.

Stokes, S C. 1999. 'Political Parties and Democracy'. Annual Review of Political Science 2.

Strøm, K \& W C Müller. 1999. 'Political Parties and Hard Choices'. In W C Müller \& K Strøm (eds). Policy, Office, or Votes? How Political Parties in Western Europe Make Hard Decisions. Cambridge: Cambridge University Press.

Suttner, R. 2003 Transformation of Political Parties in Africa Today. South Africa: Friedrich Ebert Stiftung.

Thomas, L S. 2001. 'Studying the Political Party-Interest Group Relationship'. In C S Thomas (ed). Political Parties and Interest Group: Shaping Democratic Governance. Colorado \& London: Lynne Reinner Publishers.

Tordoff, W. 1988. 'Parties in Zambia'. In V Randall (ed). Political Parties in the Third World. London: Sage Publications.

United Nation Development Programme (UNDP). 1997. Governance for Sustainable Human Development. Policy Paper. Online at <magnet.undp.org/policy/ chapter1.htm\#b>

US Department of Defence. 2003. Transformation Planning Guidance (TPG), April.

Van Biezen, I. 2003. Political Parties in New Democracies: Party Organisation in Southern and East-Central Europe. Basingstoke: Palgrave Macmillan.

Van de Walle, N \& K S Butler. 1999. 'Political Parties and Party Systems in Africa's Illiberal Democracies'. Cambridge Review of International Studies 13(1).

Wanjohi, N G. 2003. 'Sustainability of Political Parties in Kenya'. In M A Mohamed Salih (ed). African Political Parties: Evolution, Institutionalisation and Governance. London: Pluto Press.

Ware, A. 1996. Political Parties and Party Systems. New York: Oxford University Press. Welch, G \& Z Nuru. 2006. Governance for the Future: Democracy and Development in the Least Developed Countries. Washington, DC: UNDP. Also online at $<$ www.undp.org/governance/docs/Policy-Pub-LDCReport.pdf>

Wolinetz, S. 1991. 'Party System Change: The Catch-all Thesis Revisited'. West European Politics 14.

2002. 'Beyond the Catch-all Party: Approaches to the Study of Parties and Party Organization'. In R Gunther, J Ramón Montero \& J J Linz (eds). Political Parties: Old Concepts and New Challenges. Oxford: Oxford University Press.

World Bank. 1989. Sub-Saharan Africa: From Crisis to Sustainable Growth. Washington, DC: The World Bank.

—. 1997. World Development Report. Washington, DC: World Bank.

Yanai, N. 1999. 'Why Do Political Parties Survive?' Party Politics 5(1). 